\title{
Peach Brown Rot: Still in Search of an Ideal Management Option
}

\author{
Vitus Ikechukwu Obi ${ }^{1,2}$, Juan José Barriuso ${ }^{2}$ and Yolanda Gogorcena ${ }^{1, * \text { (D) }}$ \\ 1 Experimental Station of Aula Dei-CSIC, Avda de Montañana 1005, 50059 Zaragoza, Spain; \\ vitemma@live.com \\ 2 AgriFood Institute of Aragon (IA2), CITA-Universidad de Zaragoza, 50013 Zaragoza, Spain; \\ barriuso@unizar.es \\ * Correspondence: aoiz@eead.csic.es; Tel.: +34-97-671-6133
}

Received: 15 June 2018; Accepted: 4 August 2018; Published: 9 August 2018

\begin{abstract}
The peach is one of the most important global tree crops within the economically important Rosaceae family. The crop is threatened by numerous pests and diseases, especially fungal pathogens, in the field, in transit, and in the store. More than $50 \%$ of the global post-harvest loss has been ascribed to brown rot disease, especially in peach late-ripening varieties. In recent years, the disease has been so manifest in the orchards that some stone fruits were abandoned before harvest. In Spain, particularly, the disease has been associated with well over $60 \%$ of fruit loss after harvest. The most common management options available for the control of this disease involve agronomical, chemical, biological, and physical approaches. However, the effects of biochemical fungicides (biological and conventional fungicides), on the environment, human health, and strain fungicide resistance, tend to revise these control strategies. This review aims to comprehensively compile the information currently available on the species of the fungus Monilinia, which causes brown rot in peach, and the available options to control the disease. The breeding for brown rot-resistant varieties remains an ideal management option for brown rot disease control, considering the uniqueness of its sustainability in the chain of crop production.
\end{abstract}

Keywords: Prunus persica; Monilinia spp.; host and pathogen; stone fruits; crop protection; plant breeding

\section{Introduction}

Peaches (Prunus persica (L.) Batsch), nectarines (P. persica var. nectarina (Aiton) Maxim), and paraguaya (P. persica (L.) Batsch var. platycarpa L.H. Bailey) are members of the Prunus genus which includes hundreds of economically important fruits such as the cultivated almond (Prunus dulcis (Mill.) D.A. Webb), the apricot (Prunus armeniaca (L.)), the European plum (Prunus domestica (L.)), the Japanese plum (Prunus salicina (L.)) and the cherry (Prunus avium (L.)) [1].

The peach is the third most important global tree crop within the economically important Rosaceae family after apples (Malus spp.) and pears (Pyrus spp.), and its largest producer is China, followed by European countries (Spain and Italy) and the United States (Figure 1). Available information in EUROSTAT shows that in the European Union (EU) agriculture, the fruit sector weighs $6.7 \%$ of the agricultural output, peaches being the third product after apples and oranges [2].

Numerous fungal pathogens infect the peach in both the pre- and the post-harvest states. The prominent ones include Rhizopus nigricans Ehrenb., Mucor spp., Botrytis cinerea Pers. Fr., Geotrichum candidum Link ex Pers., Alternaria spp., Aspergillus spp., Penicillium spp., and Monilinia spp. [3]. However, for the purpose of this work we shall focus on the principal casual pathogens of brown rot (BR) in peaches. Species of Monilinia are associated with brown rot, which is the most economically 
important disease of stone fruits worldwide [4,5]. Brown rot incidence (BRI) in peaches greatly varies during the fruit development [6]. Fruits are less susceptible to brown rot at the early stage of formation, becoming resistant during pit hardening, and increase susceptibility afterwards $[7,8]$.

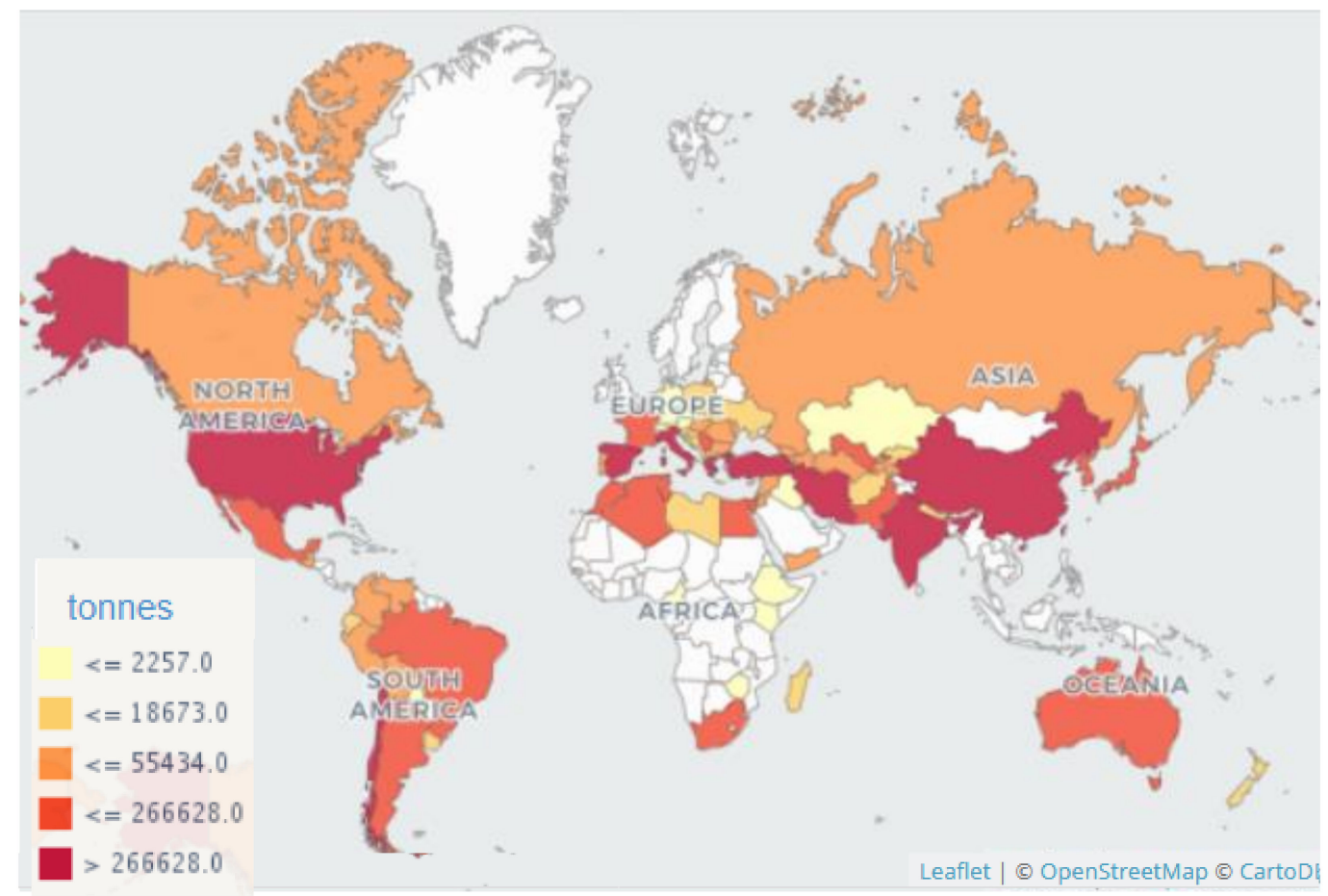

Figure 1. Global map of peach and nectarine production. Source: http:/ / www.fao.org/faostat/en/ \#data/QC/visualize ([9]).

The causal agent of brown rot (Monilinia spp.) is a polycyclic pathogen [10] involving infection sequence repeated several times throughout the annual growth cycle of the host. The fungus survives the winter in mummified fruits [11], in canopy or in the ground [12], in fruit peduncles [13], in cankers on twigs, in spurs, and in branches [5,14,15]. These propagules [16] serve as sources of primary inoculum to infect blossoms, buds, and young shoots, establishing a source of secondary inoculum.

The universal annual losses from the epidemic have been estimated at 1.7 billion Euros [17]. In some cases, the disease has been associated with up to $80 \%$ of the incidence of fruit loss after harvest $[18,19]$, mostly under favorable environmental conditions for the commencement and growth of the diseases in the orchard.

There are various control and management strategies for the brown rot epidemic in peach cultivation. These options include conventional, biological, chemical, physical, botanical, and host-resistance techniques [4]. In the present review, we will focus on peaches, their interaction with species of Monilinia, and the available management strategies, with a view to developing a sustainable peach-breeding scheme.

\section{The Peach}

The origin of the peach is traceable to the Western part of China in the Eastern Asian continent, where it was cultivated for 4000 years and from where it was subsequently dispersed to Europe, Africa, and America [20]. The documentation of the first cultivated peach was recorded in Chinese manuscripts as early as the 10th Century BC. In China, the species presents the greatest richness in germplasm and has the largest collections of peach germplasm, with wild peaches still growing today [20-22]. 
The five most important countries for the production of peaches and nectarines are shown in Figure 1 [9]. China was the leader in production (14.47 MT (million tons)), followed by Spain (1.53 MT), Italy (1.43 MT), USA (0.93 MT), and Greece $(0.85 \mathrm{MT})$. The cultivation area in the world revealed that China is the leader with 838,768 ha and in the EU-28, Spain is the largest $(86,896 \mathrm{ha})$, followed by Italy $(69,005 \mathrm{ha})$ and Greece $(44,271 \mathrm{ha})$. In the EU, the cultivation and production are concentrated in the countries of the Mediterranean region, including Spain, Italy, Greece, and France, owing to the fact that the potential risk of damage from frost [23] is less than in the countries of the Northern part of Europe. Hence, most plant disease models are known to use different climatic variables and operate at a different spatial and temporal scale from the global climate models [24].

\subsection{Geography and Ecological Requirements of Peaches}

Geographically, global commerce has brought peach tree cultivation into both the Northern and Southern hemispheres [20] which experience contrasting summers and winters allowing for year-round availability. Peach trees require wet winters and hot dry summers and will not flourish in Oceanic climates [20].

Oftentimes, the cropping practices employed in a region for the production of peaches are principally determined by the different environments, water and nutritional requirements [20]. These plantation crops, though cultivated mainly in temperate zones, between $30^{\circ}$ and $45^{\circ}$ latitude $\mathrm{N}$ and $\mathrm{S}$, are not very resistant to the cold and they require up to 400 to 800 cold hours for flowering and have a good fruit set [20]. Minimum winter temperatures and spring frosts are important limiting factors in quality peach production. In temperate zones, flower bud death due to chilling injury induced or triggered by excessive cold during shooting or flowering [20]. Therefore, peaches cannot be grown successfully where temperatures normally fall to $-23{ }^{\circ} \mathrm{C}$ and $-26^{\circ} \mathrm{C}$ [20]. On the other hand, they do not grow satisfactorily where winters are too mild, and most varieties require some winter chilling to induce them to burst into growth after the annual dormant period.

Edaphically, the peach grows best on well-drained sandy or gravelly loams. Hence, the peach seedling is susceptible to both calcareous and waterlogged soils $[20,25]$. Nevertheless, the search for iron chlorosis-tolerant rootstocks using peach-almond hybrids has led to a selection of highly vigorous rootstocks such as GF 677 [26], which were widely adopted in the Mediterranean basin countries. Later, other rootstocks tolerant to calcareous and waterlogged soils have been released [27,28]. Nitrogen-rich soils exceptionally support the performance of peach crops [29] when soil acidity is maintained above $\mathrm{pH}$ 6.0. On the contrary, a soil $\mathrm{pH}$ below 5.5 is deleterious to peach tree growth, fruit yield and size, and tree longevity [30].

\subsection{Botany and Susceptibility of Peaches to Infection by Monilinia spp.}

The peaches could be classified according to the flesh type (non-melting or melting), flesh color (yellow, orange, white, or yellow/orange), fruit shape (round or platicarpa), fruit type (peach or nectarine), and stone type (clingstone or freestone) [31]. Among the available varieties of peaches, the yellow-fleshed varieties, such as the famous Elberta, Redhaven, and Halford, are preferred in North America (USA), while both yellow- and white-fleshed types are popular in Europe [20,32]. Most yellow-fleshed peaches are clingstone varieties, while white-fleshed peaches fall into the freestone category [31]. The greatest difference between the two is really about texture and taste. The Spanish peach industry, hitherto, was based on yellow, non-melting fleshed and clingstone types; however, the replacement of the Spanish traditional varieties by introduced ones, mostly from North America, has promoted melting flesh cultivars [32].

Peach trees under commercial cultivation (Figure 2) are usually kept between three and four meters [33]. Peach trees are self-pollinating and have an impressive blossoming. Flowers are borne in the leaf axils along the shoots of the previous season's growth. The five petals, usually pink or pink-salmon [31], five sepals and three whorls of stamens are fused on the hypanthium, that forms the base of the flower that can be showy or non-showy [31]. The fruit is a large drupe with a thin 
epidermis, a pulpy mesocarp, and a woody endocarp containing the seed, more or less globose, with a longitudinal groove and a cavity around the peduncle. Ordinarily, the skin of most ripe peaches is downy or fuzzy; however, the nectarines are a class of peaches with smooth skins [33].

The degree of susceptibility to infection by Monilinia spp. is variable throughout fruit development. The susceptibility is high during the early stages of fruit development, decreases during the green fruit or pit hardening stage, and increases again during the ripening period [8,34]. Phenologically, peach fruit development generally undergoes four stages (S-I to S-IV, Figure $2 \mathrm{f}-\mathrm{g}$ ) from flowering to maturation: Fruit set (S-I), characterized by cell division and elongation, also referred to as the exponential growth phase; pit hardening (S-II), when the endocarp hardens to form the stone and scarcely increases the fruit size; pre-climacteric phase (S-III), which is another exponential growth phase, with a resumption of rapid cell division and fruit size enlargement; the climacteric stage (S-IV), with final cell division, cell expansion, and ripening/maturation $[35,36]$.
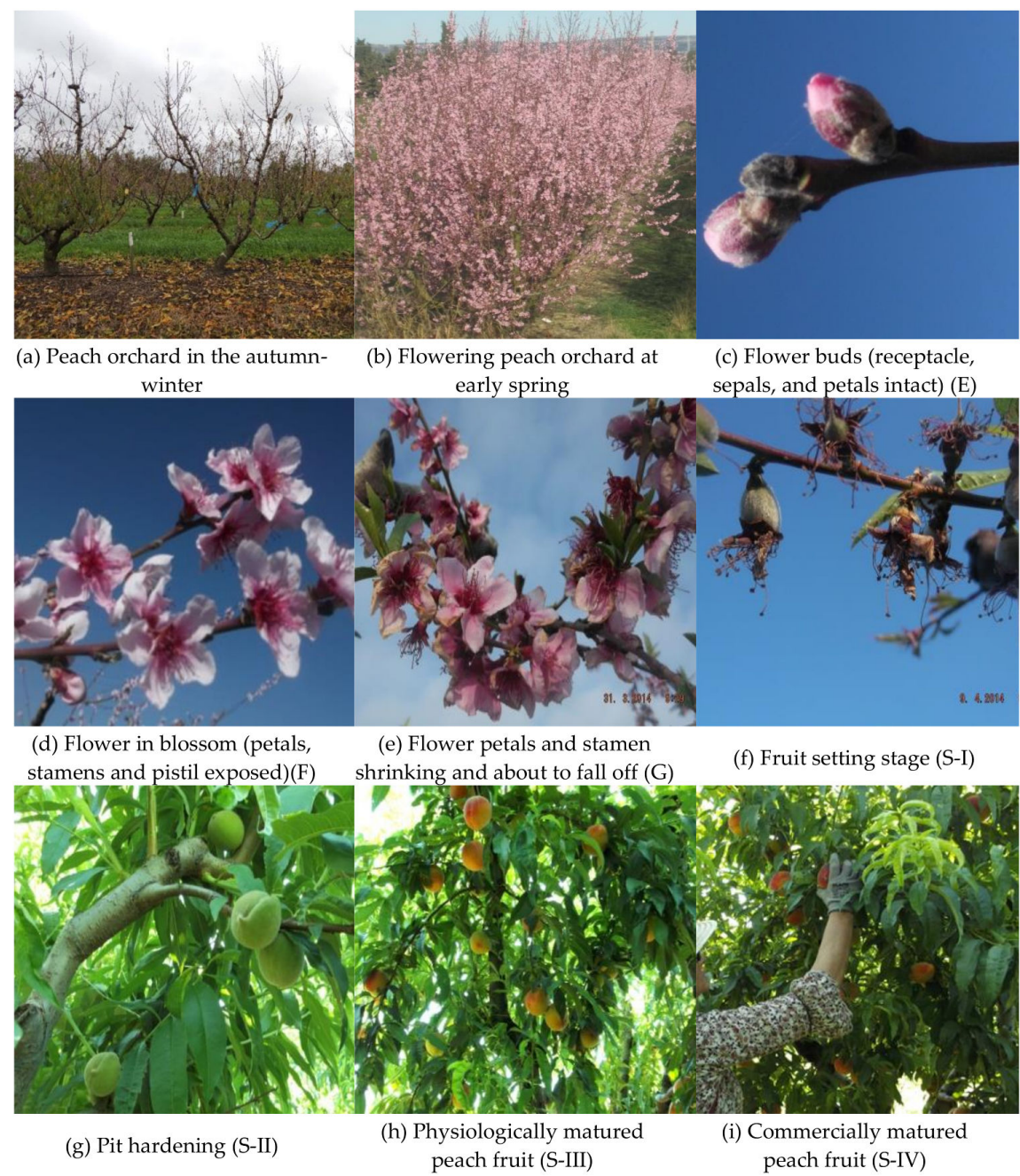

Figure 2. Phenological growth of peach trees from one season to the other (bare orchard to commercial maturity) at the Aula Dei peach germplasm collection. (a) Peach orchard in the autumn-winter, (b) Flowering peach orchard at early spring, (c) Flower buds (receptacle, sepals, and petals intact) (E), (d) Flower in blossom (petals, stamens and pistil exposed) (F), (e) Flower petals and stamen shrinking and about to fall off (G), (f) Fruit setting stage (S-I), (g) Pit hardening (S-II), (h) Physiologically matured peach fruit (S-III), (i). Commercially matured peach fruit (S-IV). Capital letters in brackets: phenological growth stages according to the Baggliolini codes (c-e) and fruit growth $(\mathbf{f}-\mathbf{i})[35,36]$. 
Peach fruit nutrients have been found to be at their peak in the first stages of fruit formation and gradually reduce as the fruit develops [37]. Therefore, the period of highest brown rot susceptibility conversely coincides with the lowest peach nutrient contents.

\subsection{Economic Significance of Peaches in EU-28}

The production of peaches and nectarines in the campaign 2017-2018 for the main EU-28 producers is estimated at 4 million tons (MT), $6 \%$ higher compared to the previous cropping season 2016-2017 (Table 1).

Table 1. Production and estimation of peaches and nectarines (in tons) in the EU-28 main producing countries in different campaigns.

\begin{tabular}{cccc}
\hline Country & $\mathbf{2 0 1 5 - 2 0 1 6}$ & $\mathbf{2 0 1 6 - 2 0 1 7}$ & $\mathbf{2 0 1 7 - 2 0 1 8}$ \\
\hline Spain & $1,581,510$ & $1,475,849$ & $1,487,444$ \\
Italy & $1,408,504$ & $1,262,127$ & $1,362,749$ \\
Greece & 777,160 & 788,120 & 910,000 \\
France & 217,146 & 207,004 & 214,800 \\
\hline
\end{tabular}

Source: United States Department of Agriculture (USDA) [38], Spanish Ministry of Agriculture (MAPAMA) [39].

This production is attributable to an expected increase in most of the major producers; hence, the EU has remained a net exporter of peaches and nectarines, with total exports largely exceeding imports for three seasons running (Figure 3). However, there was a steady drop in the EU export from the 2014-2015 to the 2016-2017 campaign (Figure 3), undoubtedly suggesting an increase in the percentage of internal consumers of this precious product within the EU-28 during this period.

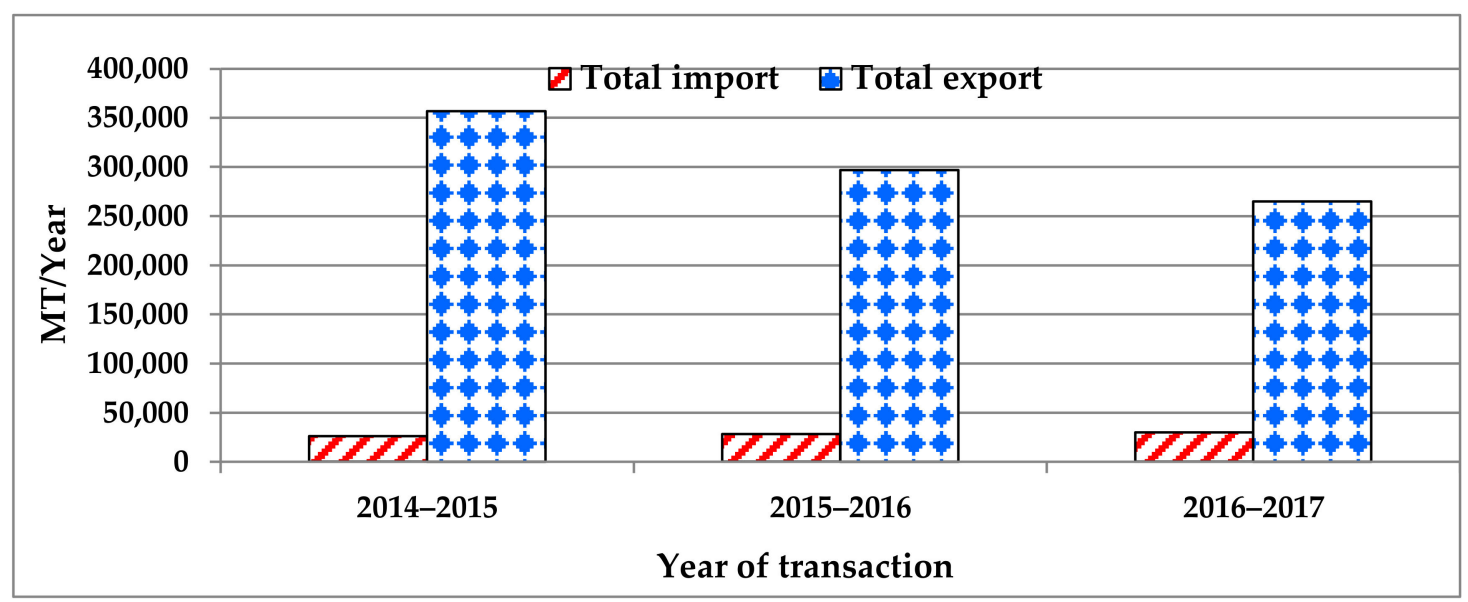

Figure 3. Total import and export of EU-28 of fresh peaches and nectarines during three seasons. (2014-2017). Source: USDA [38]. Metric tons (MT = $1000 \mathrm{~kg}$ )

According to a special global report, Spain has become, in the last four seasons, the largest peach and nectarine producer in the EU-28 [38]. The reasons for this feat were attributed to factors including a steady performance from the country's most important regions (Aragón, Cataluña, and Murcia) together with improved productivity in other regions and an increase of early and mid-season peaches, mainly due to good flowering and fruit set and the introduction of newer varieties in recent years [38]. According to the Spanish Ministry of Agriculture (MAPAMA) [39], peach and nectarine production in Spain for 2017-2018 is projected to reach almost $1.487 \mathrm{MT}$, accounting for an almost $40 \%$ share of the total EU-28 peach and nectarine production. This is $0.7 \%$ higher compared to the previous season and is due to favorable weather conditions that resulted in a production characterized by very good quality and calibers. 
Incidentally, the optimum peach commodity production is hindered by the brown rot epidemic, with significant economic consequences [40]. In recent times, orchards have been abandoned before harvest because of the severity of this disease [4]. Consequently, the universal annual losses from the epidemic have been estimated at 1.7 billion Euros [17]. In Spain, particularly, the disease has been associated with as high as $80 \%$ of fruit loss after the harvest [3], mostly under favorable environmental conditions for the commencement and growth of the diseases in the orchard.

\section{Brown Rot}

\subsection{Monilinia spp.}

Monilinia belongs to the group of necrotrophic fungi (Ascomycota) in the order of Heliotiales (Leotiales), a large family of inoperculate discomycetes which includes both human and plant pathogens [41]. The teleomorph genus is Sclerotinia spp. (position in classification: Sclerotiniaceae, Helotiales, Leotiomycetidae, Leotiomycetes, Pezizomycotina, Ascomycota) [42]. The species of Monilinia are among the major causal organisms of brown rot disease in various orchard tree crops including: (a) Stone fruits $[4,40,41,43,44]$, such as apricots [45,46], peaches $[5,8,47,48]$, nectarines [48], cherries [49], and plums [45]; (b) Almonds [50] occasionally; and (c) Some pome fruits [51,52], such as pears [51], apples [53], and quinces [54].

Monilinia laxa (Aderhold and Ruhland) honey is one of the most important species of Monilinia globally associated with the brown rot in stone and pome fruits [4]. Monilinia fructigena (Honey), Monilinia fructicola (G. Winter) [5] and Monilinia polystroma (G. Leeuwen) $[48,55]$ are other important species. The disease is highly destructive for peaches from fruit formation to storage, but additional losses are caused by the blighting of flowers and twigs.

Hitherto, M. laxa and M. fructigena were reported to be the two most important fungi causing the disease in peaches, particularly in Spain until 2006. Then, M. fructicola was detected for the first time in peach orchards in the Ebro valley, Lerida, Spain [5], and spread, displacing M. laxa, a supposedly indigenous pathogen [56], and reaching the same level of diffusion [56]. Nowadays, in Spain, both Monilinia species (M. laxa (Aderhold and Ruhland) and M. fructicola (G. Winter) Honey) coexist in the field [4,47]. It can be inferred that M. laxa and M. fructicola have similar epidemiological physiognomies [57], considering such an inherent ecological coexistence. Incidentally, the epidemiology and management of $M$. fructicola have been most extensively studied, whereas the equally important $M$. laxa has received less attention [4].

Changes in the frequency of occurrence of different fungal pathogen species may be due to fungicide resistance. Egüen et al. [18] suggested that fungicide resistance of the $M$. fructicola population is co-acting with other factors such as an adaptation in the pathogen, changing the frequency of occurrence of the three Monilinia species in Spain. The displacement of M. laxa by M. fructicola in Spain has also been attributed to its conjugational potency related to sexual exchange and ability to produce ascopores from pseudosclerotial mummified fruits and their gradual process of a sexual propagation [56]. M. laxa is not known to produce apothecia [56], while M. fructicola does, from which ascopores can easily be disseminated in the spring for possible infection in the fruiting season [58].

\subsection{Geographical Distribution of the Species of Monilinia}

The occurrence and distribution of the species of Monilinia, (Figure 4) are global, having been detected in virtually all the continents of the world $[4,40]$ where potential hosts are cultivated. Their presence is established especially when peach fruits are moved (imported) from one country of origin to another [4]. Presently, six closely related species of brown rot fungi have been reported, particularly in stone and pome fruit, including Monilinia laxa (Aderhold and Ruhland) Honey, M. fructicola (G. Winter) Honey, M. fructigena (Honey), M. polystroma (G.C.M. van Leeuwen), M. yunnanensis (M.J. Hu and C.X. Luo), and M. mumecola (Y. Harada, Y. Sasaki, and T. Sano) $[40,59,60]$. 
The geographic distribution of these species differs across the world (Figure 4). Hence, M. laxa and M. fructicola are found more globally distributed $[4,40,59,60]$ across the six continents of the world. M. fructigena is mostly restricted to the European and Asian countries $[4,59,60]$ although its presence has also been reported in Africa (Morocco and Egypt). M. fructigena was a quarantine pathogen for Canada, the USA, Australia, and New Zealand but now it is not present there (Figure 4). M. polystroma [55] has been reported in Serbia [61], Japan, Hungary, China, Croatia, and Slovenia [59]; M. mumecola in Japan and China [59] and M. yunnanensis [62] is only domiciled in China [59]. Consequently, it is no longer relevant to affirm that the different species of Monilinia are distributed in specific regions considering the obvious ubiquitous pattern of spread.

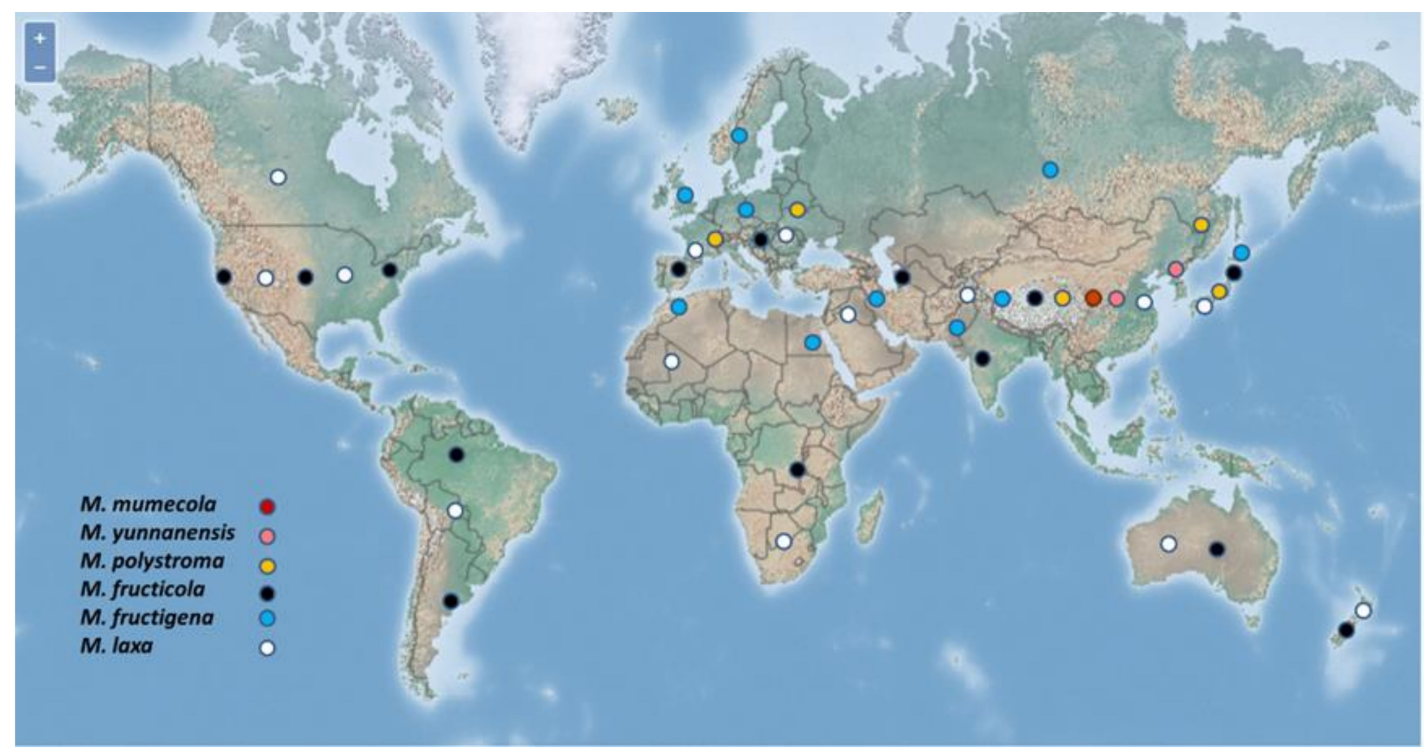

Figure 4. Global map showing the present continental distribution of the species of Monilinia spp. Source: https:/ / www.cabi.org/isc/ ([63]).

\subsection{Life Cycle of Species of Monilinia}

The species of Monilinia, as a polycyclic pathogen [10], produces numerous secondary cycles throughout the annual growth cycle of the host (Figure 5). The fungus survives winter (and is transmitted from year to year) in several structures, such as mummified fruits $[11,64,65]$, in canopy or on the ground [12], fruit peduncles [13], cankers on twigs, spurs, and branches [14,15]. These propagule-infested materials, according to Gell et al. [16], serve as sources of primary inoculum, and, when weather conditions are suitable, spores can infect blossoms, buds, and young shoots, thus a establishing a source of secondary inoculum [16].

Thus far, the main primary inoculum in Spanish orchards is the mycelium and conidia present in the mummies found in affected trees or on the orchard floor [66]. It has also been shown that there is a positive correlation between the number of mummies in the trees and the incidence of post-harvest fruit rots $[16,66]$.

It is also very important to note here that brown rot propagules are practically everywhere during the fruit-ripening period. In addition, infection is almost certain to occur if the weather is moist for long periods [13] and if the fruit skin is bruised [67].

Brown rot is spread by the dispersal of Monilinia propagules through other microorganisms [20], wind and water [68], insects, birds, and man [69]. They are also transferred by rain/overhead irrigation splashes [13]. Finally, insect and hail wounds, fruit cracking, limb rubs, twig punctures, and a variety of picking and packing injuries are predisposing factors that greatly increase fruit losses due to brown rot [70]. Hence, a clarion call for an adequate orchard sanitary [13,71] observation at all times, especially at the onset of spring. Young uninjured fruits are thus, always fairly, safe from infection. Special care 
should be taken during harvesting and packing to prevent puncturing or bruising of the ripe fruit. In addition, wild or neglected stone fruit trees that serve as collateral reservoirs for the disease must always be removed [70].

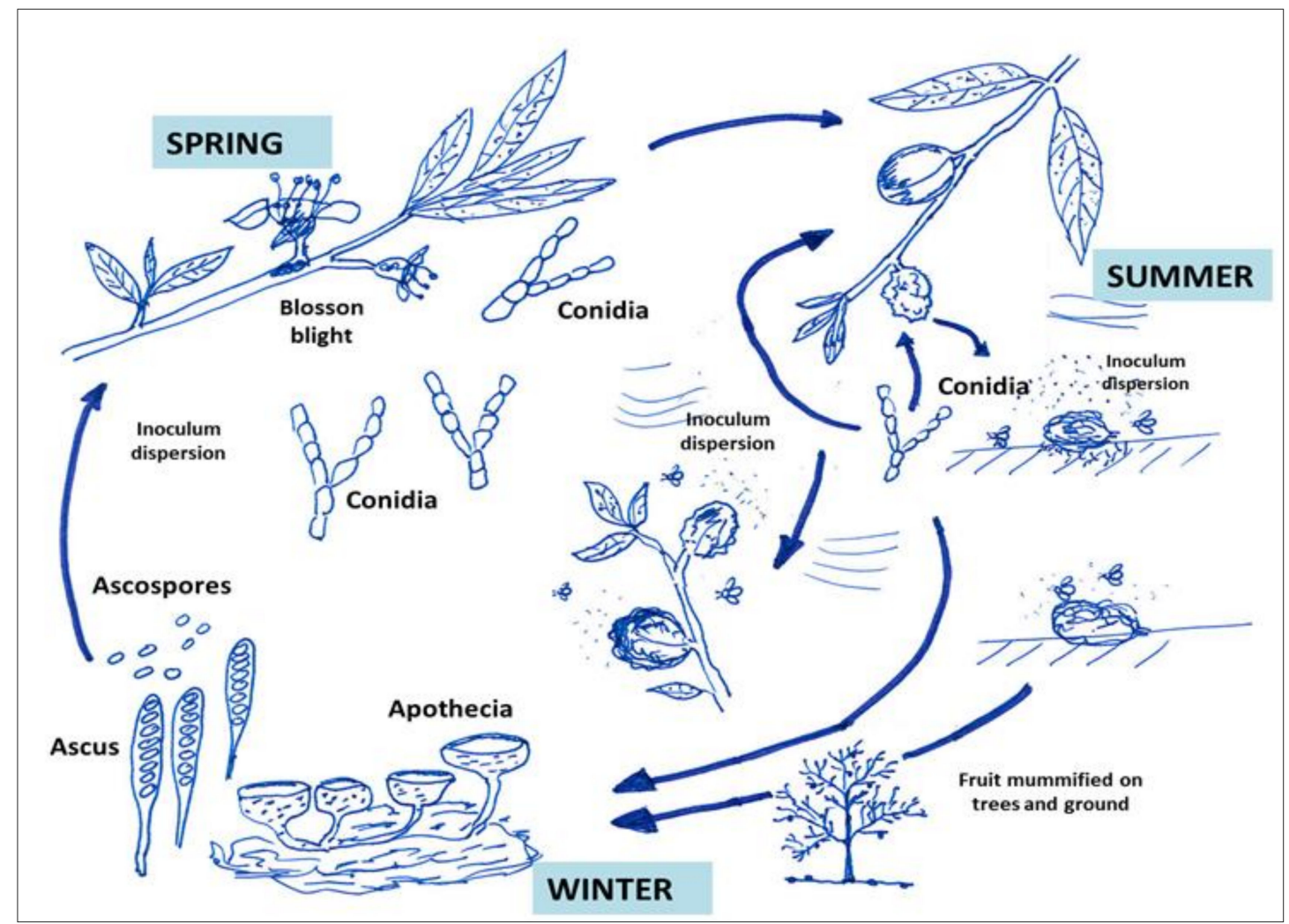

Figure 5. Brown rot disease cycle.

For M. fructicola, an occasional source of inoculum can be sexual spores (ascospores) [4]. Around the blossoming time, a mummified fruit produces up to 20 or more small, tan, cup-like structures on slender stalks that are called apothecia (sg. apothecium) (Figure 5). As an apothecium matures, it becomes thicker, and the cup opens to a bowl-like disc 3 to $12 \mathrm{~mm}$ in diameter across the top. The inner surface of each of these bowl-like discs is lined with thousands of spore-containing sacs (asci). At this stage, the slightest disturbance or air movement will cause an apothecium to effectively discharge millions of spores. If a film of water (either from dew, rain, or irrigation-especially overhead irrigation) is present for five hours or longer, the spores can germinate and penetrate the plant [4].

Infected blossoms soon wilt, and tan-gray tufts, composed of masses of another type of asexual spore (conidia), develop on the outside of the flower shuck [66]. If the infected blossom does not drop off, the fungus soon grows through the pedicel on the twig, initiating a canker. Masses of conidia are soon produced on the newly cankered twig surface during moist periods throughout the early part of the fruit development period (Figure 5). When entering the summer period, spores are easily detached and, just like the ascospores, are mainly wind-borne. Then, the brown rot disease cycle continues as indicated in Figure 5. However, when conditions (weather) are unfavorable, the infection can remain latent [72] until fruit maturity, the optimal time of disease development $[8,57,73]$.

M. laxa, as a mycelium, overwinters in twig cankers, blighted blossoms parts, peduncles, and mummified peach fruits in the canopy or on the ground [12]. In addition, in the spring, mycelia propagules begin to sporulate and produce abundant conidia which initiate infections on close contact with susceptible tissues, such as blossoms, spurs, and twigs [74]. Fruits are susceptible to M. laxa 
infection particularly in the time of fruit maturation, which may lead to a disease epidemic by harvest and infected mummified fruits [74].

\subsection{Ecological Requirements of Monilinia Species}

Epiphytologically, the knowledge of the ecological requirements of Monilinia species is essential in the development of a predictive model to comprehend the epidemiology of brown rot and provide adequate disease management strategies [75,76]. Important abiotic factors determining the potential for conidia germination and the growth of Monilinia propagules on the host exterior include temperature $(\mathrm{T})$, water availability (water activity $\mathrm{a}_{\mathrm{w}}$ ), and wetting period $(\mathrm{W})[77,78]$. The effects of these factors on Monilinia pathogenicity combine with those exerted by the moisture content of the spore, the age of the spore, and the inoculum concentration. According to Casals et al. [78], more than $80 \%$ of viable conidia of M. fructicola and M. fructigena can germinate at $25^{\circ} \mathrm{C}$ and $0.99 \mathrm{a}_{\mathrm{w}}$ within $2 \mathrm{~h}$, whereas those of $M$. laxa require $4 \mathrm{~h}$. The three species can germinate at a temperature range from 0 to $35{ }^{\circ} \mathrm{C}$ under 0.99-0.95 $\mathrm{a}_{\mathrm{w}}$. The optimum temperatures for M. fructicola and M. laxa were determined at 24.5 and $19.8^{\circ} \mathrm{C}$, respectively [79]. The estimated maximum temperature for lesion development is higher for M. fructicola $\left(30^{\circ} \mathrm{C}\right)$ than for $M$. laxa $\left(10^{\circ} \mathrm{C}\right)$, inferring that $M$. fructicola is favored by a warmer weather compared to M. laxa. Hence, Bernat et al. [57] reported that $M$. fructicola is better adapted to high temperatures, whereas M. laxa is better adapted to low temperatures. These authors observed that, under optimal conditions, $M$. laxa is as aggressive as $M$. fructicola on peach fruits. M. laxa, unlike the others (M. fructicola and M. fructigena), has the potential to germinate in the absence of free water $\left(\mathrm{a}_{\mathrm{w}}\right)$ in the host, which makes this fungus relatively more virulent. The minimum germination temperatures estimated for $M$. fructicola and M. laxa were 4.7 and $0{ }^{\circ} \mathrm{C}$, respectively [78]; nevertheless, the conidia of M. laxa have been reported to germinate even at $-4^{\circ} \mathrm{C}$ [75].

Though the lowest storage temperature for stone fruit is $0{ }^{\circ} \mathrm{C}$, the conidia of the species of Monilinia, in general, could have the potential to germinate at a temperature range from 0 to $35^{\circ} \mathrm{C}$ of $2 \mathrm{~h}$ from the initial exposure in vitro, especially when the value of free water $\left(\mathrm{a}_{\mathrm{w}}\right)$ or relative humidity (RH) under the equilibrium condition is under $0.99-0.90 \mathrm{a}_{\mathrm{w}}$. Hence, the pathogen on the peach skin can germinate under $0-40{ }^{\circ} \mathrm{C}$ at $100-80 \% \mathrm{RH}$ [66]. However, an optimum temperature range for brown $\operatorname{rot}$ (moniliosis) initiation in peaches at the commercial stage is $22.5-25{ }^{\circ} \mathrm{C}$, at which more than $79 \%$ of fruits could be infected under a wetting period of $12 \mathrm{~h}$ minimum [77].

\subsection{Characterization and Identification of Monilinia Species}

Monilinia species, including M. laxa (Aderhold and Ruhland) Honey, M. fructigena (Honey), M. fructicola (G. Winter), and M. polystroma (G. Leeuwen) appear difficult to differentiate from one another. However, a relative distinction is possible through the use of "CMM", which is the observation and combination of cultural, morphological, and molecular methods [80]. The main characteristics of the morphological variance in cultures (classical) of M. laxa and the other three related EU-28 Monilinia species are presented in Table 2.

\subsubsection{Classical Methods}

As indicated in Table 2, classical quantitative or qualitative characterizations and identification in species of Monilinia are possible by combining morphological data, such as conidial dimensions and the length of the germ tube [81], with cultural physiognomies [82], such as growth rate, growth pattern, and colony color index (CCI) [83].

Though with some similarities, in germ tube per conidia and colony colors, particularly between M. laxa and M. fructicola, there are peculiar pronounced characteristics in the culture of the former (M. laxa) that distinguish it from the others, including the formation of the smallest conidia $(11-13 \times 8-9.5 \mu \mathrm{m})$, a short and twisted germ tube, a shorter germ tube $(150-350 \mu \mathrm{m})$ at $22{ }^{\circ} \mathrm{C}$ after more than $18 \mathrm{~h}$ of incubation (Table 2). 
Table 2. Main differences in culture between Monilinia laxa and the other three associated EU-28 Monilinia species.

\begin{tabular}{|c|c|c|c|c|c|}
\hline Characteristics/Pathogen & M. laxa & M. fructicola & M. fructigena & M. polystroma & Source \\
\hline Conidia dimension & $11-13 \mu \mathrm{m} \times 8-9.5 \mu \mathrm{m}$ & $12.5-14.5 \mu \mathrm{m} \times 8-10 \mu \mathrm{m}$ & $17.5-20.5 \mu \mathrm{m} \times 10.5-12.5 \mu \mathrm{m}$ & $13-17 \mu \mathrm{m} \times 9-10.5 \mu \mathrm{m}$ & EPPO Bull [80]; van Leeuwen et al. [55] \\
\hline Number of germ tube & $1 /$ conidia & $1 /$ conidia & $2 /$ conidia & $2 /$ conidia & EPPO Bull [80]; van Leeuwen et al. [55] \\
\hline Form of germ tube & Short and twisted & Long and straight & Long and straight & Long and straight & EPPO Bull [80]; van Leeuwen et al. [55] \\
\hline Size description & Smaller & Larger & Similar to M. laxa & Similar to M. fructigena & EPPO Bull [80]; van Leeuwen et al. [55] \\
\hline Length of germ tube $\left(>18 \mathrm{~h}\right.$ at $\left.22^{\circ} \mathrm{C}\right)$ & $150-350 \mu \mathrm{m}$ & $750-900 \mu \mathrm{m}$ & $600-900 \mu \mathrm{m}$ & $700-1000 \mu \mathrm{m}$ & EPPO Bull [80]; van Leeuwen et al. [55] \\
\hline Sporulation & Delayed and sparse & Quick, intense and abundant & Sparse & Sparse & EPPO Bull [80]; van Leeuwen et al. [55] \\
\hline Sporulation range* & $0-3.7$ & $2.8-5.3$ & - & na & Hu et al. [62] \\
\hline Mean sporulation * & 1.8 & 3.9 & na & na & Hu et al. [62] \\
\hline Colony color & Hazel/Isabelline (greyish-brown) & Hazel/ Isabelline (greenish-brown) & Pale luteous (yellowish/creamy) & Pale luteous (yellowish/creamy) & $\begin{array}{c}\text { EPPO Bull. [83]; Petróczy et al. [61]; } \\
\text { Petróczy et al. [84] }\end{array}$ \\
\hline Mycelium in distinct layers/colony rosetted & $\begin{array}{l}\text { Resetting (mycelium in distinct } \\
\text { layers on top of each) }\end{array}$ & No/rare & $\begin{array}{l}\text { On distinct tufts; rings of aerial } \\
\text { mycelium }\end{array}$ & $\begin{array}{l}\text { Intense formation of black, } \\
\text { stromatal plates initiated after } \\
10-12 \text { days incubation }\end{array}$ & $\begin{array}{c}\text { van Leeuwen et al. [55]; EPPO Bull. [80]; } \\
\text { Petróczy et al. [84] }\end{array}$ \\
\hline Colony rosette with black arcs & Yes & No & No & No & EPPO Bull [80]; van Leeuwen et al. [55] \\
\hline Concentric ring of spores & No & Yes & Sometimes & Sometimes & van Leeuwen et al. [55] \\
\hline Colony margins & Serrulated/lobed & Not lobed but entire & Not lobed but entire & Not lobed but entire & $\begin{array}{l}\text { van Leeuwen et al. [55]; } \\
\text { Petróczy et al. [84] }\end{array}$ \\
\hline Range of colony growth rate $(\mathrm{mm} / 24 \mathrm{~h})$ & $2-11$ & $9-20$ & $0-12$ & nd & de Cal et al. [81]; van Leeuwen et al. [55] \\
\hline $\begin{array}{l}\text { Mean colony growth rate }(\mathrm{mm} / 24 \mathrm{~h} \text { ) } \\
\text { (in continuous darkness) }\end{array}$ & 6 & 13 & 3.7 & 7 & $\begin{array}{l}\text { EPPO Bull [83]; Hu et al. [62]; } \\
\text { Petróczy et al. [84] }\end{array}$ \\
\hline Growth rating scale & Low & High & Low-moderate & Moderate & van Leeuwen et al. [55] \\
\hline
\end{tabular}

* Log-transformed number of conidia per $\mathrm{cm}$, (Hu et al.) [62]; nd = not detected, na = not available. 
On potato dextrose agar (PDA), the colonies of $M$. laxa are greyish-brown, while the colonies of $M$. fructigena are yellowish or creamy (Table 2). In addition, colony formation in M. laxa is in distinct layers on top of each other (resetting) with black curvatures and never associated with a concentric ring of spores as observed for Monilinia fructicola. In addition, in M. laxa, the colony margins are serrulated or lobed with low growth rating scale (Figure 6).

In general, the identification in culture of Monilinia species is often difficult because their appearance varies from isolate to isolate within the same species [85]. For this reason, the aforementioned quantitative methods do not allow an effective screening; therefore, there is a need for standardized conditions (molecular methods) starting with pure cultures.

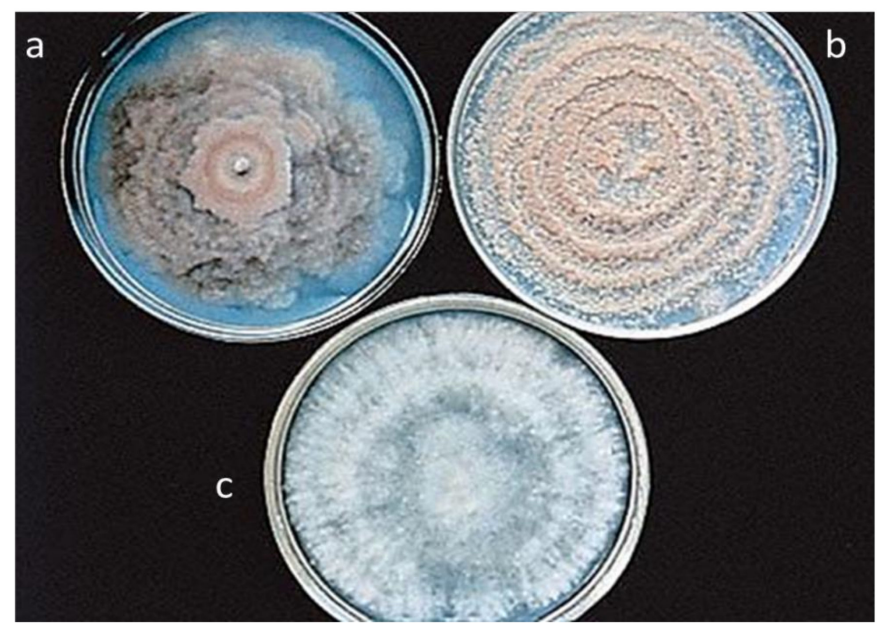

Figure 6. Pure cultures on potato dextrose agar (PDA) showing the morphologies of the three major species of Monilinia at 10 days $\left(22^{\circ} \mathrm{C}\right)$ of incubation: (a) M. laxa, (b) M. fructicola, and (c) M. fructigena. (Photograph Courtesy APS Press). Reproduced with permission from Compendium of Stone Fruit Diseases, 1995, American Phytopathological Society, St. Paul, MN, USA.). https:/ /www.apsnet.org/ edcenter/intropp/lessons/fungi/ascomycetes/Pages/BrownRotStoneFruits.aspx [86].

\subsubsection{Molecular Methods}

Since the first decade of this century, several methods of molecular characterization to distinguish Monilinia species $[4,40,85,87,88]$ exist. Most of the molecular methods for characterization or disease detection include the Polymerase Chain Reaction (PCR), which is an in vitro, primer-directed, enzymatic reaction capable of exponential amplification of DNA. A recent review published in 2017 [89] revealed that the molecular techniques used for Monilinia characterization include many PCR variants [PCR, nested PCR (nPCR), cooperative PCR (Co-PCR), multiplex PCR (M-PCR), real-time PCR (RT-PCR), and DNA fingerprinting] and fluorescence in situ hybridization (FISH), which are all based on DNA analysis.

The method using Monilinia-specific DNA primers of the internal transcribed spacer (ITS region) was employed by Forster and Adaskaveg [90] in the detection of early brown rot infections in cherry fruits. With the same technique (ITS), Ioos and Frey [91] used the endpoint PCR to study the genomic variation within M. laxa, M. fructigena, and M. fructicola and designed primers to successfully achieve results directly on the diseased fruits. This method is considered the conventional PCR standard test (EPPO Bulletin 2015). A species-specific detection of $M$. fructicola from California stone fruits and flowers was developed by Boehm et al. [92] using the PCR technique in 2001. Côté et al., in 2004 [85], worked on the characterization and identification of M. fructigena, M. fructicola, M. laxa, and M. polystroma using a multiplex PCR. Later in 2007, Gell et al. [87] utilized two different PCR approaches for the universal diagnosis of brown rot and identification of Monilinia spp. in stone fruit trees combining a set of universal primers with the inclusion of an internal control for the diagnosis of 
brown rot caused by the three more important species. More recently, the RT-PCR method developed by Brouwershaven et al. [88] was validated against all four brown rot-causing Monilinia species ( $M$. laxa, M. fructicola, M. fructigena, and M. polystroma). In 2016, Guinet et al. [93] used a multiplex real-time PCR (RT-PCR) to detect and discriminate the three common species of Monilinia (M. laxa, M. fructicola, and M. fructigena) on Prunus and Malus. Other authors, [94] applying high-resolution melting (HRM) techniques, distinguished six different species of Monilinia in peach (M. laxa, M. fructicola, M. fructigena, M. mumecola, M. lithartiana, and M. yunnanensis) by analyzing the melting curve of amplicons of two universal primer pairs.

Recently, Garcia-Benitez [95] compared the overnight freezing-incubation technique (ONFIT) and the modified RT-PCR quantitative polymerase chain reaction (qPCR)-based methods of van Brouwershaven et al. [88] to detect latent brown rot infections and, subsequently, distinguish between the Monilinia spp. in flowers and peach fruits. The same authors [96] later validated the method to test performance accuracy, analytical specificity, sensitivity, repeatability, and reproducibility, as defined by standard PM7/98 of the European Plant Protection Organization (EPPO) for detection of Monilinia spp., demonstrating that was more sensitive, reliable, and quicker than ONFIT for detecting a latent brown rot infection.

The merits of DNA-based detection methods include reliability, timesaving, and higher sensitivity and specificity, when compared to the traditional and serological assays techniques employed during the processes of artificial cultivation $[93,95]$. For example, the molecular technique of multiplex RT-PCR assay (One step) developed in 2016 by Guinet et al. [93] is efficient and prompt in characterizing the three major species of Monilinia responsible for brown rot (M. laxa, M. fructicola, and M. fructigena). These authors also inferred that the exceptional reliability of their results is of paramount importance in the framework of phytosanitary regulations, considering that the performance data were generated, and the assay was fully validated in accordance to the EPPO guidelines [72].

In summary, molecular biology-based methods are progressively providing the means for a timely identification of quarantine plant pathogens including some species of Monilinia. The methods do not necessitate the isolation of the particular species of Monilinia and, therefore, significantly accelerate the identification process compared with methods based on quantitative characteristics. Finally, these methods can potentially be improved to directly and specifically identify the species infecting peaches. Their prominence, no doubt, is also necessitated by the inefficient classical screening systems, however, there are limitations associated with molecular assays

In the last decade, several protocols could not distinguish some Monilinia species, although modern RT-PCR has been modified to overcome this [59,95]. The methods of PCR primers and protocols for M. fructicola as documented by Förster and Adaskaveg [90], Boehm et al. [92], and Ma et al. [97], though discriminating M. fructicola from M. laxa, have not been validated for distinguishing $M$. fructicola from $M$. fructigena.

The characterization methods of Ioos and Frey [91], Miessner and Stammler [98], and Hily et al. [99] reliably differentiated three species of Monilinia (M. fructigena, M. fructicola, and M. laxa), but were practically unable to distinguish $M$. fructigena from M. yunnanensis. Similarly, the methods developed by Ioos and Frey [91] and Ma et al. [97,100] did not discriminate between M. mumecola and M. laxa. In addition, the method developed by Hily et al. [99] did not differentiate M. mumecola from M. fructicola, and the methods of Miessner and Stammler [98] and Hily et al. [99] also could not discriminate between M. yunnanensis and M. mumecola. Moreover, some investigators [96] in their study of RT-PCR detection of latent Monilinia spp. infection in nectarine flowers and fruits could only prevent cross-detection by stringently including an allelic discrimination step (with an extra cost) in the qPCR runs, to enable the differentiation between M. fructicola and M. laxa [95].

Finally, results from multiplexed and quadruplexed PCR [101] in particular, have demonstrated that this molecular assay is sensitive and specific. Other investigators [102,103] have recommended that for optimum performance and accurate identification, particularly when using PCR tests, and regardless of the DNA extraction method, chemicals' and thermocyclers manufacturers, or staining 
methods, there is the exigency for a careful selection of species-specific primer pairs for the correct molecular diagnosis of Monilinia species. In all, it has been recommended [96] that additional research of new primers and probes for the characterization of Monilinia species should be conducted to make the method more transferable among qPCR platforms and laboratories [96]. We refer to Raja et al. [104] for more information on the merits and demerits of the use of "molecular tools" in fungi detection and identification.

\section{Host-Pathogen Interactions}

Brown rot is the pathologic result of a parasitic interaction between the species of Monilinia and the peach [105]. In this association, and depending on the region of first contact (blossom, spur, twig, branch, fruit), the pathogen initiates and promotes rot in preharvest and after harvest $[87,106]$. Hence, the pathogen's activity on the host is highly destructive from the flowering stage, through the peach formation stage, to storage [107], thereby creating an infection chain, as shown in Figure 7. Brown rot is a polycyclic epidemic [10]; hence, various secondary or monocyclic components of the brown rot infection sequence are generated throughout the annual growth cycle of the host. This biological proficiency conversely causes a grave impairment of the harvest, storage, and commercial shelf life of the product $[87,108]$. Interestingly, as it is found in any pathogen-host association, the growth and development of brown rot is influenced by different physicochemical conditions, such as temperature and water activity [109], light, aeration and pressure [110], $\mathrm{pH}$, and titratable acidity of the fruits $[8,111,112]$.

During such impending epiphytotics, the aforementioned physicochemical factors influence the microbial activity, determining either the growth and reproduction or the inhibition of activity and the inactivation of the pathogen. In particular, the $\mathrm{pH}$ and titratable acidity (TA) are interrelated concepts of organic acids $[113,114]$ controlling physicochemical factors that act in an additive and interactive mode to inhibit the pathogen's metabolic pathways [112].

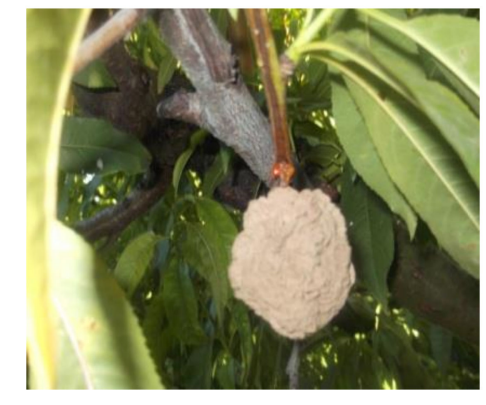

(a)

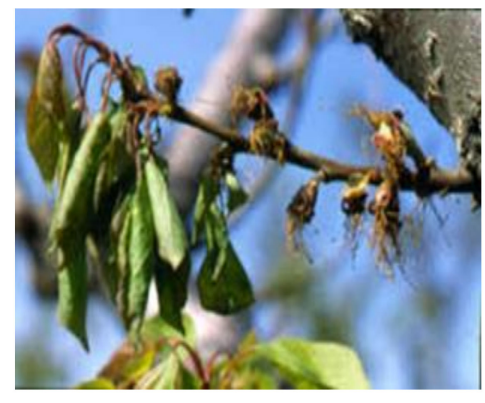

(b)

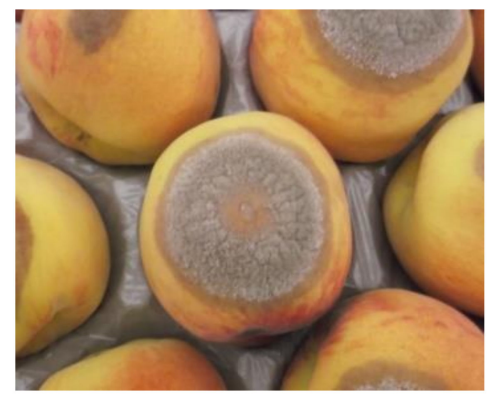

(c)

Figure 7. Infection chain of Monilinia laxa in host peach. (a) Mummified peach; (b) blighted blossoms; (c) infected peach fruits.

In peach fruits, acidity is an important genetic quality trait [113] which influences both perception of sourness and sweetness found in varying proportions depending on the cultivar and the ripening stage [115]. The influence of $\mathrm{pH}$ and TA on fungal-host interactions is documented $[8,116]$. Some fungal species prefer neutral to slightly alkaline conditions [110]. However, the Monilinia species, in general, are acidophilic and therefore prefer acidic conditions for their growth $[8,110]$. Results by Holb [111] have shown that healthy peach fruits are quite acidic $(\mathrm{pH}<3.5)$, but the $\mathrm{pH}$ levels rapidly increase in infected fruits reaching values of 4.6-5.4 depending on the cultivar and fungus isolate. On the contrary, other authors have found that species of Monilinia can acidify the host tissue of peaches and nectarines from $\mathrm{pH}$ values of 4.50 and 4.45 , to $\mathrm{pH}$ values of 3.75 and 3.90 , respectively [117]. 


\section{Management Strategies to Control Brown Rot in Peaches}

The weather conditions have been reported to influence the percentage of latent infections in peach and nectarine flowers and fruits [73] and remain a significant factor that must be considered in the effective management of this disease. This is a pathological situation where the infected fruit can remain asymptomatic (latent), and visual decay symptoms only develop during the late ripening period and after harvesting [57], particularly when there is a favorable ambient condition. Most stone fruits with a latent brown rot infection caused by Monilinia do not develop visible signs of disease until their arrival at the market or consumers' home. A rapid, accurate, and reliable [118] detection of Monilinia latent infections [95] is recommended to prevent and control the dispersion of Monilinia spp. in infected localities and non-infected countries [72].

There are other control and potential management options available for the brown rot epidemic in peaches, which include agronomical practices, biological, chemical, physical and biofungicides treatments, and host resistance [4].

\subsection{Agronomical Management}

Agronomical/cultural management is one of the first methods in all disease control, and in case of BR one of the most effective. Sanitation by prompt removal and adequate destruction of all infected parts (spurs, twigs and branches, mummified fruits, etc.) in winter, helps break the life cycle of the disease [16] in individual trees and the entire orchard as whole, and has been reported to keep brown rot below damaging levels. It is important to rake up and remove any fallen fruit or debris from under trees [13]. Prune trees to remove fruit mummies from the trees immediately after harvest or during the dormant season [70]. Pruning trees occasionally also helps to improve air circulation and add to fruit quality [113]. It is also advisable to use Tanglefoot ${ }^{\circledR}$ Pruning Sealer to seal all cuts and wounds and protect against insects [70], and disease organisms [20]. Avoid rain irrigation but instead use drip system under the canopy to keep from wetting blossoms, foliage and fruit [4]. Timely application to avoid rapid depletion of fungicide residue. In a commercial setting, all fruit not harvested or affected must be removed from the orchard, preventing to become mummies, thereby minimizing overwintering inoculum for next year's crop. Possible artificial fruit injury must be avoided. Hence thinned green fruits [119], undetached but injured green fruits are all potential source of inoculum and must be removed and adequately destroyed [120]. Tillage operations such as harrowing also help in destruction and burial of remnant propagules on the orchard. Carry out regular weeding and removal of wild or neglected stone fruit trees that serve as reservoirs for the disease [70]. Finally, it is very important to avoid excess water and Nitrogen application [20].

\subsection{Biological Control Agents}

Evidence abounds on the practical and biological control possibilities for diseases of the Monilinia species (Table 3) [121,122]. Biological control also refers to the use of formulations of living organisms (biofungicides) to control the activity of plant pathogenic fungi and bacteria [123].

An example of the use of the biological control agents (BCA) is EPS125 (Pantoea agglomerans, a Gram-negative bacterium) [124], which is effective in preventive treatments for the control of brown rot in several stone fruit crops, including peach. This study showed the ability of EPS125 to colonize, rapidly grow, and survive in wounds, indicating that its main mechanisms of action is mediated by cell-to-cell interactions in the absence of major toxicological effects, which constitute interesting traits for its effective use as a biofungicide in commercial conditions. 
Table 3. Biological control agents (BCAs) against Monilinia spp. in peach.

\begin{tabular}{|c|c|c|c|c|c|c|}
\hline Biological Agents & Formulation & Target Pathogen & Disease & Application Phase & Effectiveness & Reference \\
\hline Penicillium frequentans & P. frequentans & Monilinia laxa (Aderh. \& Ruhl.) Honey & Twig blight & Preharvest & Effective and practical & de Cal et al. [121] \\
\hline Penicillium purpurogenum & strain 828 & $\begin{array}{l}\text { Monilinia laxa (Aderh. \& Ruhl.) Honey and } \\
\text { Fusarium oxysporum f. sp.lycopersici (Snyder \& Hansen) }\end{array}$ & Shoot canker & Preharvest & Enhanced mycoparasitism & Larena and Melgarejo [122] \\
\hline Pantoea agglomerans & EPS125 & $\begin{array}{l}\text { Monilinia laxa (Aderh. \& Ruhl.) Honey and } \\
\text { Rhizopus stolonifer (Ehrenb., Fr.) }\end{array}$ & Brown rot & Postharvest & Potentially effective & Bonaterra et al. [124] \\
\hline Epicoccum nigrum & Fresh conidia & Monilinia spp. & Brown rot & $\begin{array}{c}\text { Preharvest } \\
\text { (bloom and pre-harvest) }\end{array}$ & $\begin{array}{l}\text { Reduced brown rot at } \\
\text { post-harvest }\end{array}$ & Larena et al. [125] \\
\hline Bacillus subtilis & CPA-8 & $\begin{array}{l}\text { Monilinia laxa (Aderh. \& Ruhl.) Honey and } \\
\text { Monilinia fructicola (Wint.) Honey }\end{array}$ & Brown rot & Postharvest & $\begin{array}{l}\text { Effective growth inhibition } \\
\text { achieved }\end{array}$ & Yánez-Mendizábal et al. [126] \\
\hline Penicillium frequentans & $\begin{array}{l}\text { FOR1, FOR2 and } \\
16 \text { others }\end{array}$ & Monilinia spp. & Brown rot & $\begin{array}{c}\text { Preharvest } \\
\text { (blossom to harvest) }\end{array}$ & $\begin{array}{l}\text { Good potential for } \\
\text { development }\end{array}$ & Guijarro et al. [127] \\
\hline Bacillus amyloliquefaciens & CPA-8 & $\begin{array}{l}\text { Monilinia laxa (Aderh. \& Ruhl.) Honey and } \\
\text { Monilinia fructicola (Wint.) Honey }\end{array}$ & Brown rot & Preharvest & $\begin{array}{l}\text { Potential alternative against } \\
\text { Monilinia spp }\end{array}$ & Gotor-Vila et al. [128] \\
\hline
\end{tabular}


Larena et al. [125] carried out seven field experiments in peach orchards located in three different countries (Spain, Italy, France), to develop an effective and practical method of controlling brown rot disease caused by Monilinia spp. by the pre-application of Epicoccum nigrum. The result of their work demonstrated that E. nigrum applications, alone or in combination with fungicides treatments, to peach trees in the field reduced post-harvest brown rot. Bacillus spp. are among the most recommended bacteria to use against plant diseases, including brown rot, and marketed as commercial products (QST 713 strain (Table 4) [4]. Yánez-Mendizábal et al. [126] used Bacillus subtilis (CPA-8) strain to control Monilinia spp. in peaches and indicated that fengycin-like lipopeptides play a major role in the biological action against Monilinia laxa and M. fructicola. In addition, antagonistic microorganisms such as Penicillium frequentans and Bacillus amyloliquefaciens $[127,128]$ are examples of practical control measures, for peach production.The potential of B. amyloliquefaciens CPA-8 to control Monilinia spp. has been tested under field conditions, and CPA- 8 remained active on the treated peach fruit surface at harvest and after harvest on self [128].

According to records, the number of new bio-pesticide registrations in the EU-28 is growing steadily, but they currently represent only $2.5 \%$ of the pesticide market [4]. However, there are several issues to consider before marketing the bio-pesticides. For example, Giobbe et al. [129] found that a biofilm-forming strain of Pichia fermentans proved to be most effective in controlling brown rot on apple fruit but pathogenic on peach fruit when co-inoculated into artificial wounds with a phytopathogenic isolate of $M$. fructicola. The authors, therefore, emphasized the need for a thorough risk assessment before allowing any deliberate release of bio-control agents, considering the associated potential effects, such as displacement of nontarget organisms, allergenicity to humans and other animals, toxicity, pathogenicity, and genetic stability. Hence, any minimal potential biohazard is inherent to the application of any bio-control agents [129] in peach commodity.

\subsection{Fungicide Treatments}

Synthetic fungicides such as cyproconazole, iprodione, and thiophanate-methyl [18], have been used to control Monilinia in the orchards in conventional and integrated pest management programs depending of the country. As an example in the European Union, the main conventional products, allowed in Spain including application doses and maximum residue limit (MRL) for European countries is shown in Table 4. Only two active substances are approved for the control of this fungus in commodities post-harvest product store: fludioxonil, with two different formulations (Table 4) (fludioxonil 23\% (Solution Concentrate, SC) W/V and fludioxonil 60\% (SC) W/V), currently registered until 31 December 2019, and pyrimethanil 30\% (GE) W/W, valid until 30 April 2019 [39]. The CODEX Alimentarius as part the World Health Organization (WHO) and the Food and Agriculture Organization (FAO) provides users with a list of MRL tolerances by commodity, pesticide, or functional class of the database at http:/ / www.codexalimentarius.net/pestres/data/index.html [130]. Details for fungicides treatments, doses and MRL allowed in the United States are also provided in Adaskaveg et al. [130].

Furthermore, only eighteen active ingredients from more than 197 bio-fungicidal formulations, registered in the national pesticide guide website of the "Ministerio de Agricultura, Pesca, Alimentación y Medio Ambiente de España", are authorized for use in the control of the brown rot of peach in Spain (Table 4). A permission limit (deadline) for fungicide use in stone fruit production is also provided. The same fungicide can be used in both pre- and post-harvest treatment, with corresponding restrictions in each case. 
Table 4. Chemical and biological formulations used against Monilinia in stone fruit production in Spain.

\begin{tabular}{|c|c|c|c|c|}
\hline Formulation & $\begin{array}{c}\text { Number of } \\
\text { Comercial Products }\end{array}$ & Doses/Application & $\begin{array}{c}\text { SP } \\
\text { (Days)/MRL }\end{array}$ & Permissible Limit \\
\hline Sulphur $80 \%+$ Cyproconazole $0.8 \%$ (WG) W/W & 1 & $0.1-0.2 \% /$ pulverization & $14 / 0.1$ & $21 / 11 / 2018$ \\
\hline Cyproconazole $10 \%$ (WG) W/W & 1 & $0.01-0.02 \%$ & $14 / 0.1$ & $12 / 09 / 2018$ \\
\hline Cyprodinil 37.5\% + fludioxonil 25\% (ESP) (WG) W/W & 1 & $0.8 \mathrm{~kg} / \mathrm{ha} ; 1$ application & $7 / 2$ & $30 / 04 / 2019$ \\
\hline Copper (II) hydroxide $35 \%$ (WG) W/W & 23 & $0.2-0.25 \%$ & $\mathrm{NA} / 5$ & $31 / 01 / 2020$ \\
\hline Iprodione $75 \%$ (WG) W/W & 1 & $0.1 \%$ at a maximum of 2 applications $/$ season and less than $1 \mathrm{~kg} / \mathrm{ha}$ & $14 / 10$ & $31 / 10 / 2018$ \\
\hline Mancozeb 20\% + Dicopper chloride trihydroxide 30\% (WP) W/W & 20 & $2.5-3 \mathrm{~kg} / \mathrm{ha}$ & $14 / 2$ & $31 / 01 / 2020$ \\
\hline Mancozeb $75 \%$ (WG) W/W \& 80\% & 35 & $0.2 \%$ at a maximum of 4 applications/season and less than $2 \mathrm{~kg} / \mathrm{ha}$ & $30 / 2$ & $30 / 01 / 2020$ \\
\hline Thiophanate-methyl 50\% (SC) W/V; 70\% (WG) W/W & 4 & $0.09 \%$ at 1 application per season & $14 / 2$ & $31 / 10 / 2019$ \\
\hline Mancozeb $8 \%$ + Cuprocalcium sulphate $20 \%$ (WP) W/W & 4 & $4-5 \mathrm{~kg} / \mathrm{ha}$ & $\mathrm{NA} / 2$ & $31 / 01 / 2020$ \\
\hline Myclobutanil $4.5 \%(\mathrm{EW}) \mathrm{W} / \mathrm{V}$ & 1 & $0.66-1.1 \%$ & $7 / 0.5$ & $31 / 05 / 2021$ \\
\hline Dicopper chloride trihydroxide $11 \%+$ Cuprocalcium sulphate $10 \%$ (WP) W/W & 1 & $0.35-0.55 \% ; 1.75-5.5 \mathrm{~kg} / \mathrm{ha}$ to a maximum of $7.1 \mathrm{~kg} / \mathrm{ha}$ per year & $\mathrm{NA} / 5$ & $31 / 01 / 2020$ \\
\hline Copper (I) oxide $40 \%$ (01) W/W & 12 & $0.65 \%$ at a maximum of $3.75 \mathrm{~kg} / \mathrm{ha}$ per year & $\mathrm{NA} / 5$ & $31 / 01 / 2020$ \\
\hline Copper (I) oxide 50\% (WP) W/W \& 52\% & 47 & $0.3 \% ; 2.5 \mathrm{~kg} / \mathrm{ha}$ & $\mathrm{NA} / 5$ & $31 / 01 / 2020$ \\
\hline Copper (I) oxide 70\% (WG) W/W & 16 & $0.15 \% ; 1.35 \mathrm{~kg} / \mathrm{ha}$ & $\mathrm{NA} / 5$ & $31 / 01 / 2020$ \\
\hline Tribasic copper sulphate $40 \%$ (WG) W/W & 14 & $0.2-0.3 \% ; 1-3.75 \mathrm{~kg} / \mathrm{ha}$ per year & $\mathrm{NA} / 5$ & $31 / 01 / 2020$ \\
\hline Tebuconazole $25 \%$ (WG) W/W & 11 & $0.05-0.075 \% ; 0.75 \mathrm{~kg} / \mathrm{ha}$ & $7 / 0.6$ & $31 / 08 / 2020$ \\
\hline Fenbuconazol 2.5\% (EW) W/V & 2 & $0.2-0.6 \% ; 3 \mathrm{~L} / \mathrm{ha}$ & $3 / 0.5$ & $30 / 04 / 2022$ \\
\hline Bacillus subtilis (Strain QST 713) $15.67 \%\left(5.13 \times 10^{10} \mathrm{CFU} / \mathrm{g}(\mathrm{WP}) \mathrm{W} / \mathrm{W}\right.$ & 1 & $2.5-4 \mathrm{~kg} / \mathrm{ha}$ & NA & $30 / 04 / 2019$ \\
\hline \multicolumn{5}{|c|}{ Total active ingredients applicable in preharvest peach and nectarine bio-fungicidal control (18) } \\
\hline Fludioxonil $23 \%$ and $60 \%(S C) \mathrm{W} / \mathrm{V}$ & 2 & $0.3-0.4 \%$ & $\mathrm{NA} / 10$ & $12 / 31 / 2019$ \\
\hline Pyrimethanil 30\% (GE) W/W & 1 & $6 \mathrm{~g} / \mathrm{tm}$ & $\mathrm{NA} / 5$ & $30 / 04 / 2019$ \\
\hline \multicolumn{5}{|c|}{ Total active ingredients applicable in postharvest peach and nectarine bio-fungicidal control (2) } \\
\hline Total number of commercial bio-fungicidal products allowed in Spanish peach & narket (197) & & & \\
\hline
\end{tabular}

ESP (Spain); NA (not applicable); WP (wettable powder); SC (suspension concentrate); EW (emulsion of oil in water); CFU (colony-forming units) tm (metric tons); Source: MAPAMA [39]. 


\subsection{Limitations in the Use of Conventional Fungicides}

The increase in the demand for fresh fruit with reduced residual quantities [4] has placed into interrogation the continuous use of conventional fungicides (CF) in peaches. $\mathrm{CF}$ treatments often alter the micro-ecosystem and, in the long term, modify disease severity by altering the interactions among microorganisms [131]. Moreover, the toxic chemical residues pose additional ecological issues and whenever possible, integrate pest management (IPM) is recommended as a sustainable environment and cost effective crop production [132]. Furthermore, recent reports have confirmed that the differential resistance to CF in Monilinia spp. is evolving and could be modifying the frequency of occurrence of fungicide sensitive and fungicide-resistant Monilinia spp. [133]. The evolution of tolerance in species of Monilinia (M. laxa) to certain CF [134,135], the increasing cost of chemical control and post application cleanup [136], and the threat of regulatory restrictions are all yearning the need for sustainable and endearing management measures to control brown rot [137].

The regulation of $\mathrm{CF}$ use, however, has become stricter in EU countries, especially after the release of the European Directive 2009/128/EC [80]. There is also a global intensification in the number of countries advocating for reduction and waning regarding conventional chemical uses [40]. Particularly, the use of $\mathrm{CF}$ is becoming more unfashionable because of consumer demands for residue-free fruit [3]. In addition, the contamination of the environment should be avoided [138]. Finally, the steady rise in the development and occurrence of Monilinia strains resistant to CF, worldwide, has been reported [133,134,138-140]. With all these adverse implications it is, therefore, pertinent to search for alternatives control strategies as IPM with lasting effect, enhancing consumer acceptability, and at the same time environmentally friendly. Integration of techniques for pest and disease control and subsequent integration of appropriate measures that discourage the development of pest populations and keep pesticides and other interventions to levels that are economically justified and reduce or minimize risks to human health and the environment is becoming the preference all over the world [141].

\subsection{Botanical Fungicides}

Plants provide a wide range of secondary metabolites and essential oils that have an array of properties, including antimicrobial, allelopathical, bioregulatory, and antioxidative properties [142-144]. This class of plant derivatives is collectively referred to as biopesticides and includes the botanical fungicides [145]. Information, both descriptive [146] and practical (Table 5) [147,148], on biopesticidal efficacy and utility against phytopathogens abounds $[149,150]$. Some of these bioactive substances have also been assayed in vitro and in vivo [151] and found to be potent enough against brown rot of Monilinia species [151,152]. 
Table 5. Botanical products used on stone fruits in the postharvest control of brown rot.

\begin{tabular}{|c|c|c|c|c|c|c|c|}
\hline Species & Common Name & Treatment Form & Disease & Target Pathogen & Fruit Type & Effectiveness & Reference \\
\hline Mentha balsamea Wild and Ocimum basilicum $\mathrm{L}$. & $\begin{array}{l}\text { Peppermint and } \\
\text { sweet basil }\end{array}$ & Essential oils & $\begin{array}{l}\text { Yellowish, curl, brown blotch, } \\
\text { white and soft rots syndromes }\end{array}$ & $\begin{array}{l}\text { Rhizopus stolonifer (Ehrenb., Fr.); } \\
\text { Monilinia fructicola (Wint.) Honey; } \\
\text { Aspergillus niger Vantighm }\end{array}$ & Peach & High antifungal activity & Ziedan and Farrag [148] \\
\hline $\begin{array}{l}\text { Thymus vulgaris L., Eugenia caryophyllata L., } \\
\text { and } 2 \text { others }\end{array}$ & $\begin{array}{l}\text { Thyme and } \\
\text { clavero }\end{array}$ & Essential oils & Brown and gray mold rots & $\begin{array}{c}\text { Monilinia fructicola (Wint.) Honey and } \\
\text { Botrytis cinerea (Pers. Fr.) }\end{array}$ & Apricot & Good antifungal activity & Hassani et al. [150] \\
\hline Copernicia cerifera (Mill.) wax & Carnauba palm & Wax & Brown rot and Rhizopus rot & $\begin{array}{l}\text { Monilinia fructicola (G. Winter) Honey } \\
\text { and Rhizopus stolonifer (Ehrenb.) Vuill. }\end{array}$ & $\begin{array}{l}\text { Plums and } \\
\text { nectarines }\end{array}$ & Presents great potential & Goncalves et al. [151] \\
\hline Apiaceae and Asteraceae families & NA & Active substances & Brown rot & $\begin{array}{l}\text { Monilinia fructigena (Aderhold \& Ruhl.) } \\
\text { Honey }\end{array}$ & Stone fruits & Potentially effective & Ganchev [152] \\
\hline $\begin{array}{l}\text { Ocimum basilicum L., Ocimum tenuiflorum } \mathrm{L} . \\
\text { and } 2 \text { others }\end{array}$ & $\begin{array}{l}\text { Basil and holy } \\
\text { basil }\end{array}$ & Essential oils & Brown rot & Monilia laxa (Aderh. \& Ruhl.) Honey & $\begin{array}{c}\text { Peach and } \\
\text { nectarine fruits }\end{array}$ & $\begin{array}{l}\text { Potential antifungal } \\
\text { properties }\end{array}$ & Carović-Stanko et al. [153] \\
\hline $\begin{array}{l}\text { Ocimum basilicum L., Foeniculum officinale var. } \\
\text { sativum (Bertol.) Arcangel plus } 8 \text { others }\end{array}$ & Basil and fennel & Essential oils & Brown rot and grey mold rot & $\begin{array}{l}\text { Monilinia laxa (Aderh. \& Ruhl.) Honey } \\
\text { and Botrytis cinerea (Pers. Fr.) }\end{array}$ & Stone fruits & $\begin{array}{l}\text { Variability in } \\
\text { effectiveness }\end{array}$ & Lopez-Reyes et al. [154] \\
\hline Thymus vulgaris $\mathrm{L}$. and Laurus cinnamomum $\mathrm{L}$. & $\begin{array}{l}\text { Thyme and } \\
\text { cinnamon }\end{array}$ & $\begin{array}{l}\text { Essential oil } \\
\text { vapours }\end{array}$ & Brown rot & Monilinia laxa (Aderh. \& Ruhl.) Honey & Peach & $\begin{array}{l}\text { Effective in preventive } \\
\text { and curative treatments }\end{array}$ & Cindi et al. [155] \\
\hline
\end{tabular}


In an overview, Hassani et al. [150] evaluated, in vivo, the antifungal activities of four different (Thymus vulgaris (L.), Eugenia caryophyllata (L.), Cinnamomum zeylanicum (Blume) and Carum copticum (L.) plant extracts against two post-harvest pathogens ( $M$. fructicola and Botrytis cinerea) of stone fruit. Other authors [151] obtained promising results using carnauba wax in post-harvest treatments for the control of brown rot and Rhizopus rot in plums and nectarines in experiments carried out under conditions of elevated inoculum pressure for the mature fruits. Just recently, Cindi et al. [155] have recommended thyme oil for post-harvest handling as a biofumigant for peaches after indicating that thyme oil vapor effectively reduced the incidence of brown rot caused by M. laxa. These authors [155] have also suggested that thyme oil fumigation treatment can be considered as a good alternative treatment because of the low concentration effective in brown rot decay control in peaches.

Nevertheless, some authors observed some limitations in the evaluated biofungicides and made adequate recommendations accordingly. Cindi et al. [155] observed the need to conduct further studies on the effect of thyme oil fumigation on fruit quality (by evaluating sensory parameters) in naturally infected peaches after low temperature storage and in retail shelf conditions. Thyme oil influences on peach volatile compounds, such as alcohols, aldehydes, carboxylic esters, ketones, and esters, need to be investigated [155].

\subsection{Physical Treatments}

There are various options of physical control in the postharvest management of brown rot in peaches (Table 6). These include: hot water dipping [156], dry heat [138], wet heat treatment curing with chitosan or in combination with Bacillus CPA-8 [157], radio frequency (water immersion and air exposure) [108], and hydro-cooling [158].

Jemric et al. [156] indicated that it is possible to control post-harvest BR on peaches using hot water dipping (HWD) at $48^{\circ} \mathrm{C}$ for $12 \mathrm{~min}$ and on nectarine using HWD at $48^{\circ} \mathrm{C}$ for $6 \mathrm{~min}$ without a significant loss of fruit quality. However, they recommended the optimization of the method according to the cultivar to prevent the loss of acidity.

In the study of Liu et al. [138], the use of heat (wet and dry) showed that both the direct inhibition of the pathogen and the elicitation of the defense response in the fruit contributed to a significant reduction of decay in peaches. The investigators associated the control effect to the inhibition of $M$. fructicola germination and growth, intracellular reactive oxygen species (ROS) accumulation, mitochondrial impairment leading to a reduction in ATP, and induction of defense-related enzymes in peaches.

Table 6. Physical treatments to control brown rot in peach: conditions, period, and effects.

\begin{tabular}{|c|c|c|c|c|}
\hline Treatments & Temperature & $\begin{array}{l}\text { Period of } \\
\text { Exposure }\end{array}$ & Effects & Reference \\
\hline Hot water dipping (HWD) & $48^{\circ} \mathrm{C}$ & $6 / 12 \mathrm{~min}$ & $\begin{array}{l}\text { Reduced brown rot (BR) incidence and no } \\
\text { significant loss of fruit quality }\end{array}$ & Jemric et al. [156] \\
\hline Heat treatment (HT) & $40^{\circ} \mathrm{C}$ & $5 / 10 \mathrm{~min}$ & Significant reduction in peach BR & Liu et al. [138] \\
\hline Heat treatment (HT) 95\% RH & $50^{\circ} \mathrm{C}$ & $2 \mathrm{~h}$ & $\begin{array}{l}\text { Proposed as potential strategy to control } \\
\text { brown rot on peaches and nectarines }\end{array}$ & Casals et al. [157] \\
\hline $\begin{array}{l}\text { Radio frequency (RF) of } \\
\text { dipping in hot water (HT) }\end{array}$ & $60^{\circ} \mathrm{C}$ & $20 \mathrm{~s}$ & $\begin{array}{c}\text { A } 100 \% \text { BRI reduction at } 6 \text { to } 12 \mathrm{~h} \text { after } \\
\text { inoculation and } 85.7 \% \text {. BRI reduction at } 0 \\
\text { to } 48 \mathrm{~h} \text { after inoculation as compared to } \\
\text { untreated fruit }\end{array}$ & Spadoni et al. [159] \\
\hline $\begin{array}{l}\text { Radio frequency }(\mathrm{RF}) \text { at } \\
27.12 \mathrm{MHz} \text { of water } \\
\text { immersion }\end{array}$ & $20^{\circ} \mathrm{C}$ & $9 \mathrm{~min}$ & $\begin{array}{l}\text { Controlled brown rot without adverse } \\
\text { external and internal damage in both } \\
\text { peaches and nectarines }\end{array}$ & Sisquella et al. [108] \\
\hline $\begin{array}{l}\text { Radio frequency (RF) at } \\
27.12 \mathrm{MHz} \text { of exposition in air }\end{array}$ & $20^{\circ} \mathrm{C}$ & $18 \mathrm{~min}$ & $\begin{array}{l}\text { Brown rot incidence significantly reduced } \\
\text { in both peaches and nectarines of different } \\
\text { fruit size }\end{array}$ & Sisquella et al. [108] \\
\hline $\begin{array}{l}\text { Radio frequency (RF) at } \\
27.12 \mathrm{MHz} \text { of water } \\
\text { immersion }\end{array}$ & $40^{\circ} \mathrm{C}$ & $4.5 \mathrm{~min}$ & $\begin{array}{l}\text { Reduced BRI in stone fruits inoculated } \\
(0-48 \mathrm{~h}) \text { before treatment and at all maturity } \\
\text { levels evaluated in both peaches and } \\
\text { nectarines without impaired fruit quality }\end{array}$ & Sisquella et al. [160] \\
\hline $\begin{array}{l}\text { Hydro cooling (HC) and } \\
\text { water dump (WD) }\end{array}$ & $4^{\circ} \mathrm{C}$ & $30 \mathrm{~s} / 10 \mathrm{~min}$ & $\begin{array}{l}\text { Reduced brown rot incidence by } 50-77 \% \\
\text { when treated at } 2 / 24 \text { h of fruit harvest }\end{array}$ & Bernat et al. [158] \\
\hline
\end{tabular}


Casals et al. [157] used heat to protect peaches and nectarines from brown rot by exposing the fruits to $50{ }^{\circ} \mathrm{C}$ and $95-99 \%$ relative humidity (RH) for $2 \mathrm{~h}$, which should markedly eradicate the pre-existing (from the field) Monilinia spp. infections, in combination with the application of chitosan at $20^{\circ} \mathrm{C}$ for $1 \mathrm{~min}$ or the antagonist B. subtilis strain CPA-8. Other authors [159], combining hot water treatment with radio frequency (RF), after inoculating the fruit with conidia of Monilinia laxa, found BRI reduction. On the basis of these positive results, the authors recommended the techniques as a new alternative for BRI reduction in peaches.

Sisquella et al. [108] used RF (27.12 MHz) treatment to control brown rot in stone fruits either with immersion in water for $9 \mathrm{~min}$ or with exposure to air for $18 \mathrm{~min}$ as potential post-harvest alternatives for brown rot control in peaches and nectarines (Table 6). Later [160], they confirmed that the RF treatment, particularly with water immersion at $40{ }^{\circ} \mathrm{C}$ for $4.5 \mathrm{~min}$, is very promising and has commercial potential for the post-harvest control of brown rot on peaches and nectarines. Furthermore, they reported a significantly reduced brown rot incidence (BRI) in the naturally infected fruit, from $92 \%$ in control fruit to less than $26 \%$ in peaches, and complete brown rot control in nectarines [160]. However, before the commercial application of this treatment technique, these authors rightly suggested that "it is necessary to design specific equipment for water immersion to determine the economic cost of the treatment". Finally, Bernat et al. [158] applied hydro-cooling and water dump techniques to reduce BRI on peach fruit with recent infections ( 2 or $24 \mathrm{~h}$ before treatment). The techniques were able to reduce $\mathrm{BR}$ incidence in comparison to direct storage at $0{ }^{\circ} \mathrm{C}$, but not when the infections were already established ( $\geq 48 \mathrm{~h}$ before treatment).

\subsection{Host Resistance and Genetic Management}

Because of the increasing concern about the effects of biochemical fungicides (BCAs and conventional fungicides) on the environment [129] and human health [106] and about strain fungicide resistance [131], there is still a need for alternative treatments, based for instance on host resistance, which is considered one of the most cost-effective and environmentally safe strategies for disease control. Breeding for host resistance is a preventive decision measures in crop protection management. Apart from the pre-harvest issues, the length of conservation and commercial shelf life of peaches are also negatively influenced by post-harvest diseases principally associated with the brown rot, BR [108]. Nowadays, in the management of crop production, for effective and sustainable disease control, protective measures (prophylactic) are often preferred to curative measures with chemicals (chemotherapeutic). Consequently, breeders (Brazil, California, Italy, USA, France, and Spain), either individually or associated with pathologists, have concentrated their efforts on obtaining new cultivars resistant to the BR pathogen. Nonetheless, reports of resistance (in Mexican and Brazilian peaches) or tolerance (in peaches from Florida, New Jersey, and Harrow programs) to fruit brown rot in peaches exist [40,161].

Breeding for disease resistance is one of the most challenging objectives for crop improvement because disease expression is tetrahedral: Resistance is simultaneously influenced by agent, host, environment, and human management [162]. Screening for BR resistance in germplasm collections is a very time- and effort-consuming task [40]. Notwithstanding, different methodologies and varying protocols have continued to be assayed in breeding programs to evaluate the genetic resistance of stone fruit crops to fungi $[40,48,163,164]$.

The 'Bolinha' peach variety, of Brazilian origin, presents a good resistance mechanism and less susceptibility to brown rot than other varieties and, although this variety possesses relatively poor quality characteristics, it has been observed that the resistance to this disease is transmitted to its descendance $[40,58,163]$. The lack of extensive studies on $M$. laxa, in particular [4], especially on the use of tolerant varieties or genotypes with good quality characteristics in BR management and crop improvement, calls for academic and practical attention to that area.

The use of commercial varieties or genotypes with some level of disease resistance remains one of the surest and long-lasting tolerant alternatives within disease protection and improvement 
management techniques in crop cultivation [20,165]. Host tolerance to plant pathogens is important for cost-effective and environmentally safe strategies for BR management. In line with this, according to Gell et al. [87], the use of tolerant cultivars for crop improvement is the topmost principle of crop protection, as this allows plants and plant products to be protected (prophylactic) from disease epidemics $[166,167]$ and not to require cures from diseases (chemotherapeutic). Among other factors, the cultivar genotype significantly influences rot incidence and severity in stone fruits [168] and, therefore, represents an ideal modifiable element for disease control [16]. A lasting prophylactic treatment of peaches using $M$. laxa-tolerant cultivars means prevention of the pathogenic problems starting from the orchard.

Interestingly, in recent times, phytochemicals from plants and plant organs, including fruits, have drawn increasing attention due to their potent antioxidant properties and their marked effects on the prevention of various oxidative and stress-associated diseases $[169,170]$. In addition, several other studies also point to an active involvement of these phytochemicals in the protective reactions of crops against phytopathogens including fungi, bacteria, and viruses [40,171-173]. It is essential to note here that there are many studies showing that certain phenolic compounds present in peaches [174] have inhibitory effects in vitro and in vivo against Monilinia spp. [34,40]. Phenolic compounds, including caffeic and chlorogenic acids, may inhibit $M$. fructicola growth and reduce the lesion size [34]. Hence, an increase in susceptibility to brown rot infection has been associated with a concomitant decline in the concentrations of these antioxidant compounds especially in maturing fruits [175].

Breeding programs all over the world, especially the ones located in humid areas, have disease resistance as one of their top priorities, in part because the consumers' concern about chemical residues on fruits and vegetables has increased considerably. In this respect, tolerant genotypes will allow a sustainable control with zero residues in fruits and decreasing disease problems in the products during storage, leading to increased economic benefits. The total absence of treatment residues due to the use of prophylactic tolerant peach cultivars is environmentally friendly [176]. However, disease-resistant varieties are not readily available for many fruit crops [177], including commercial peach cultivars [20]. Developing peach cultivars tolerant to M. laxa requires, first of all, the identification of existing tolerant and susceptible genotypes by screening the germplasm [178].

It has been reported that, although a greater number of commercial stone fruit cultivars are susceptible to Monilinia spp. [51,179], there could exist genetic disease control elements [180,181] to be introgressed in high-quality fruit's genetic backgrounds [40]. Hence, the relative tolerance or susceptibility of fruits to disease has often been used for selecting disease-resistant genotypes for subsequent peach breeding. In addition, considering the recent drive for alternative technologies effective to control post-harvest diseases [177,182,183], in particular of stone fruits [3], any documentation of composites inhibiting BR development would have an influence on the breeding schemes and could be particularly useful to maintain fruit quality after harvesting, in the peach market. Having into account that the genetic control for the tolerance to Monilinia spp. in peach is complex, quantitative and multi-genic it would be of relevance to find candidate genes for resistance in peach. With the available version 2 of Prunus persica whole genome assembly and annotation [184] and new techniques such as GBS (Genome by Sequencing) we can search for new markers to fine mapping these quantitative regions or assay GWAs (Genome Wide Association).

\subsubsection{In Situ and Ex Situ Screening Methods to Evaluate Brown Rot Tolerance}

There are two major known systems for screening a germplasm for susceptibility or tolerance to a disease or pathogen. These systems are the in situ/field method, which mostly encompasses an evaluation of flowers, bud, twigs, and shoots, and the ex situ/laboratory method, which is mostly an assessment on the commercial fruit derived from a germplasm. A researcher, therefore, can screen these phylogenetic properties in peach, especially in the ex situ evaluation by: (a) assessment of lesion development on wounded, injured, or bruised fruit [185]; (b) assessment of lesion development on intact, uninjured, or unbruised fruit $[45,185]$; (c) assessment of spore production 
from determined lesions [46]; (d) assessment of post-harvest biodegradation from natural and latent infection; (e) assessment of cuticle thickness and firmness of commercial ripe fruits [46]. Table 7 shows some research in the ex situ evaluation of brown rot susceptibility in stone fruits. Some researchers $[45,181,185]$ inoculated both bruised and intact fruit to screen for brown rot resistance in clingstone peach germplasm. The uninjured fruit inoculation test (UFIT) and artificially injured fruit inoculation test (AIFIT) were utilized [185] to evaluate the resistance to M. fructicola in peaches, and to M. laxa in apricots, plums, and peaches [45]. Walter et al. [46] adopted the assessment for lesion development, spore production, storage performance, and cuticle thickness and firmness in screening apricot fruits for resistance to brown rot caused by Monilinia spp. Many advantages exist in support of the ex situ over the in situ method: the manipulation of the fruit is easier, the inoculum load is centrally placed on the fruit cheeks, randomly including mature and immature sides [48], and the pathogenic factors, such as lesion and fungi colonization, are adequately evaluated on each inoculated fruit. Furthermore, the ex situ methodology facilitates the post-inoculation evaluation of qualities such as firmness and soluble solid contents (SSC). In addition, the ex situ method enables the washing and disinfection of the fruits, making them pure and uncontaminated for screening against targeted pathogens. However, the artificial inoculation on unwounded fruits, though found to be a reliable method in evaluating brown rot resistance ex situ $[8,48]$, was reported to be not only lengthy and laborious but also affected by season and year variability [20,161].

Other different parts have been used to study the genetic resistance to pathogens of plant parts, such as flowers in apricots [186] and fruits in peaches [180,181,187]. Moreover, the evaluations have consistently been performed in situ with attached fruits, in natural ambient situations in the field on peaches and nectarines [180,188], or ex situ on apples [189] and stone fruits [40,190,191], involving detached apricots $[45,46]$ and peaches, under controlled conditions $[48,190,192]$. Considering the fact that several mechanisms are known to be involved in BR resistance, including phenolic concentration, thickness of the epidermis, and flesh texture, the selection should be simultaneously based on all known and unknown components. Hence, some authors $[46,179]$ have highlighted certain imperative factors to be considered when breeding for disease resistance as: (i) the adequate knowledge of the pathogenic agent, including its virulence; (ii) the knowledge of the availability, diversity, and types of genetic resistance within the breeding program as well as within the species in exam and its close relatives; (iii) the need to handle, develop, and improve the screening and phenotyping methods, including the accurate selection of the appropriate environment for the exhibition of resistance to allow its accurate tracking.

The overriding importance of the third point is underscored by Thomidis [73] who stressed that the knowledge and consideration of host specificity/non-specificity in disease management is paramount in the selection and preparation of new orchard sites and in the choice of tree species to be planted.

\subsubsection{Procedures for Spore Production and Inoculation in Lieu of Brown Rot Susceptibility Screening}

Many different procedures have been adopted in the quest to have Monilinia spores and mycelia for the purpose of artificial inoculation (Table 7). Hence, Monilinia isolates could be grown on PDA Petri dishes directly from infected organs, i.e., fruits, mummies, twigs [193], or already prepared cultures. In addition, there are numerous methodologies describing partially similar, and in some cases divergent, protocols concerning spores concentration, inoculum load, and associated variables for screening BR susceptibility in stone fruits, peach and nectarine in particular. All the techniques presented in Table 7 were accomplished ex situ (in the laboratory controlled environment) with different inoculum densities and loads [190,191].

Several studies have investigated tolerance to BR in existing phenotypes for peach breeding purposes [178,185,190,192], and, in most cases, the relationships with the fruit quality traits [187] have not been ignored [40,45,46]. Apart from peaches and nectarines [40,192], other stone fruit germplasm that are being investigated include apricots [45,46], plums [45] and cherries [49,191]. 
Table 7. Assessment conditions to screen ex situ brown rot (Monilinia spp.) susceptibility in stone fruits. References, host inoculation, spores production, and parameters recorded.

\begin{tabular}{|c|c|c|c|c|c|c|c|c|c|c|}
\hline Authors & Fruit Type & $\begin{array}{c}\text { Number } \\
\text { of Fruit }\end{array}$ & $\begin{array}{l}\text { Method of } \\
\text { Inoculation }\end{array}$ & Fruit cheek & $\begin{array}{l}\text { Source of } \\
\text { Inoculum }\end{array}$ & $\begin{array}{l}\text { Inoculum } \\
\text { Density (cfu) }\end{array}$ & Inoculum Load & $\begin{array}{l}\text { Incubation } \\
\text { Period }\end{array}$ & $\begin{array}{c}\text { Temperature/RH } \\
\text { of Incubation }\end{array}$ & Susceptibility Variables \\
\hline Biggs and Northover [190] & Peach & NA & UFIT & Randomly & PDA culture & $10^{6}-10^{3} \mathrm{~mL}^{-1}$ & $\begin{array}{c}30 \mu \mathrm{L} \text { ( } 30,000 \text { to } \\
30 \text { spores) }\end{array}$ & $144 \mathrm{~h}$ & $20^{\circ} \mathrm{C} / 60-95 \%$ & Disease severity score \\
\hline Northover and Biggs [191] & Cherry & 10 & UFIT & Suture & PDA culture & $10^{6}-10^{3} \mathrm{~mL}^{-1}$ & $\begin{array}{l}30 \mu \mathrm{L} \text { ( } 30,000 \text { to } \\
30 \text { spores) }\end{array}$ & $144 \mathrm{~h}$ & $20{ }^{\circ} \mathrm{C} / 60-95 \%$ & $\%$ BRI, lesion diameter \\
\hline Gradziel and Wang [185] & Peach & 16 & UFIT/AIFIT & $\begin{array}{c}\text { Most } \\
\text { matured }\end{array}$ & PDA culture & $2 \times 10^{4} \mathrm{~mL}^{-1}$ & $\begin{array}{c}10 \mu \mathrm{L} \\
(200 \text { spores) }\end{array}$ & $72 \mathrm{~h}$ & $22{ }^{\circ} \mathrm{C}-25^{\circ} \mathrm{C} / 95 \%$ & Lesion diameter \\
\hline Pascal et al. [45] & $\begin{array}{l}\text { Peach, Plum } \\
\text { Apricot }\end{array}$ & 10 & UFIT /AIFIT & Randomly & Natural fruit & $10^{6} \mathrm{~mL}^{-1}$ & $\begin{array}{c}20 \mu \mathrm{L} \\
(20,000 \text { spores) } \\
\end{array}$ & $240 \mathrm{~h} / 120 \mathrm{~h}$ & $23^{\circ} \mathrm{C}$ & \% BRI, lesion diameter \\
\hline Bassi et al. [192] & Peach & 15 & UFIT & Randomly & NA & $10^{5} \mathrm{~mL}^{-1}$ & NA & $168 \mathrm{~h}$ & $25 \pm 2{ }^{\circ} \mathrm{C} / 95-100 \%$ & $\%$ BRI, lesion diameter \\
\hline Walter et al. [46] & Apricot & 8 & UFIT/AIFIT & Randomly & Natural fruit & $1.5 \times 10^{4} \mathrm{~mL}^{-1}$ & $\begin{array}{c}30 \mu \mathrm{L} \\
\text { (450 spores) }\end{array}$ & $48 \mathrm{~h} / 120 \mathrm{~h}$ & $\begin{array}{c}\text { Ambient } \\
\text { temperature/lightly } \\
\text { misted with } \mathrm{dH}_{2} \mathrm{O}\end{array}$ & $\begin{array}{l}\text { Lesion area, spore counts, storage } \\
\text { rot and cuticle thickness }\end{array}$ \\
\hline Pacheco et al. [181] & Peach & 10 & UFIT / AIFIT & $\begin{array}{c}\text { Sun-exposed } \\
\text { fruit cheek }\end{array}$ & Peach fruit & $5 \times 10^{6} \mathrm{~mL}^{-1}$ & $\begin{array}{c}10 \mu \mathrm{L} \\
\text { (50,000 spores). }\end{array}$ & $120 \mathrm{~h}$ & $25^{\circ} \mathrm{C} /$ high RH & $\begin{array}{l}\text { \% BRI, average rot } \\
\text { diameter by scores }\end{array}$ \\
\hline Obi et al. [48] & Peach & 20 & UFIT & Randomly & Peach fruit & $25 \times 10^{3} \mathrm{~mL}^{-1}$ & $\begin{array}{c}25 \mu \mathrm{L} \\
\text { (625 spores) }\end{array}$ & $120 \mathrm{~h}$ & $23{ }^{\circ} \mathrm{C} / 50-60 \%$ & $\begin{array}{l}\text { Lesion diameter, colonization } \\
\text { diameter, \% BRI, disease severity }\end{array}$ \\
\hline
\end{tabular}


The parameters usually considered in such tests comprise: the extent of necrosis and intensity of sporulation [190], the percentage of fruit infection and lesion development [191], the extension of the lesion area, the spore count, the storage rot and cuticle thickness [46]. Blighted flowers, twigs, and shoots have also been used [106,194]. However, the use of the fruit in susceptibility screenings is widely used among stone fruits $[46,48]$. In this case, the BRI (percentage of fruits with lesion) is determined $[48,195]$.

\section{Conclusions}

Despite the importance of brown rot, there has been relatively little work done on the development of BR-resistant peach fruit cultivars, which is probably due to the lack of collaborative tendencies among the specialist actors involved, including farmers, breeders and phytopathologists. The lack of national projects for breeding and in general peach management (cultivation, marketing, innovations), in addition to the low price and scarce gain for the farmer, are limiting the investment for research in Monilinia spp. in many countries. Anyway, the search for phenotyping protocols to accurately characterize and evaluate brown rot infections is a mission that should always be encouraged by both breeders and pathologists in crop breeding programs. This review has clearly described the characteristic variance of the three most economically important species of Monilinia (M. laxa, M. fructicola, M. fructigena), in addition to M. polystroma, and the chemical formulations used for brown rot management in Spain, indicating also their permission limits. The continued increased demand of healthy fruit by consumers and the environmental concerns regarding the use of pesticides and associated ecomicrobial destitution require a sustainable alternative measure to combat brown rot in the peach market. In recent times, several studies have investigated tolerance to brown rot in existing peach phenotypes for peach breeding purposes and, in most cases, its relationships with the fruit quality traits. These studies have often described the use of host-resistant cultivars as a prophylactic measure rather than a chemotherapeutic strategy for brown rot management. If adequately and effectively combined with other alternative control schemes (Integrated Pest Management) and biological strategies, host resistance could promote a more sustainable peach fruit farming in the future.

Author Contributions: Y.G. conceived of this research process and edited the review; V.I.O. and J.J.B. wrote the draft paper.

Funding: This research was funded by the Spanish Ministry Economy, Industry and Competitiveness (MINECO) grant numbers AGL2014-52063R and AGL2017-83358-R.

Acknowledgments: This study has been supported by two research grants from MINECO co-financed with FEDER.

Conflicts of Interest: The authors declare no conflicts of interest.

\section{References}

1. Hummer, K.E.; Janick, J. Rosaceae: Taxonomy, Economic Importance, Genomics. In Genetics and Genomics of Rosaceae; Folta, K.M., Gardiner, S.E., Eds.; Springer: New York, NY, USA, 2009; pp. 1-17.

2. Eurostat Statistics Explained. Agricultural Production-Crops. Available online: http://ec.europa.eu/ eurostat/statisticsexplained/index.php/Agricultural_production-crops\#Fruit (accessed on 7 August 2018).

3. Usall, J.; Casals, C.; Sisquella, M.; Palou, L.; de Cal, A. Alternative technologies to control postharvest diseases of stone fruits. Stewart Postharvest Rev. 2015, 11, 1-6. [CrossRef]

4. Rungjindamai, N.; Jeffries, P.; Xu, X.M. Epidemiology and management of brown rot on stone fruit caused by Monilinia laxa. Eur. J. Plant Pathol. 2014, 140, 1-17. [CrossRef]

5. Villarino, M.; Egüen, B.; Melgarejo, P.; Lamarea, N.; Segarra, J.; Usall, J.; Melgarejo, P.; de Cal, A. Occurrence of the Monilinia laxa and M. fructigena after introduction of M. fructicola in peach orchards in Spain. Eur. J. Plant Pathol. 2013, 137, 835-845. [CrossRef]

6. Mari, M.; Casalini, L.; Baraldi, E.; Bertolini, P.; Pretella, G.C. Susceptibility of apricot and peach fruit to Monilinia laxa during phenological stages. Postharvest Biol. Technol. 2003, 30, 105-109. [CrossRef] 
7. Guidarelli, M.; Zubini, P.; Nanni, V.; Bonghi, C.; Rasori, A.; Bertolini, P.; Baraldi, E. Gene expression analysis of peach fruit at different growth stages and with different susceptibility to Monilinia laxa. Eur. J. Plant Pathol. 2014, 140, 503-513. [CrossRef]

8. Obi, V.I.; Barriuso, J.J.; Gogorcena, Y. Effects of $\mathrm{pH}$ and titratable acidity on the growth and development of Monilinia laxa (Aderh. \& Ruhl.) in vitro and in vivo. Eur. J. Plant Pathol. 2018, 151, 781-790. [CrossRef]

9. FAOSTAT. Available online: http://www.fao.org/faostat/en/\#data/QC/visualize (accessed on 8 August 2018).

10. Seem, R.C. Disease incidence and severity relationships. Ann. Rev. Phytopathol. 1984, 22, 133-150. [CrossRef]

11. Casals, C.; Segarra, J.; de Cal, A.; Lamarca, N.; Usall, J. Overwintering of Monilinia spp. on mummified stone fruit. J. Phytopathol. 2015, 163, 160-167. [CrossRef]

12. Hrustić, J.; Mihajlović, M.; Grahovac, M.; Delibašić, G.; Bulajić, A.; Krstić, B.; Tanović, B. Genus Monilinia on pome and stone fruit species. Pestic. Phytomed. 2013, 27, 283-297. [CrossRef]

13. Ritchie, D.F. Brown rot of stone fruits. Plant Health Instr. 2000. [CrossRef]

14. Melgarejo, P.; Carillo, R.; Sagasta, E.M. Potential for biocontrol of Monilinia laxa in peach twigs. Crop Prot. 1986, 5, 422-426. [CrossRef]

15. Kreidl, S.; Edward, J.; Villalta, O.N. Assessment of pathogenicity and infection requirements of Monilinia species causing brown rot of stone fruit in Australian orchards. Australas. Plant Pathol. 2015, 44, 419-430. [CrossRef]

16. Gell, I.; de Cal, A.; Torres, R.; Usall, J.; Melgarejo, P. Conidial density of Monilinia spp. on peach fruit surfaces in relation to the incidences of latent infections and brown rot. Eur. J. Plant Pathol. 2009, 123, 415-424. [CrossRef]

17. Martini, C.; Mari, M. Monilinia fructicola, Monilinia laxa (Monilinia rot, brown rot). In Postharvest Decay: Control Strategies; Academic Press Elsevier: London, UK, 2014; pp. 233-265.

18. Egüen, B.; Melgarejo, P.; de Cal, A. Sensitivity of Monilinia fructicola from Spanish peach orchards to thiophanate-methyl, iprodione, and cyproconazole: Fitness analysis and competitiveness. Eur. J. Plant Pathol. 2015, 141, 789-801. [CrossRef]

19. Teixidó, N. Brown Rot. 2018. Available online: http://www.biocomes.eu/ (accessed on 19 January 2018).

20. Byrne, D.H.; Raseira, M.B.; Bassi, D.; Piagnani, M.C.; Gasic, K.; Reighard, G.L.; Moreno, M.A.; Pérez, S. Peach. In Fruit Breeding, Handbook of Plant Breeding; Badenes, M.L., Byrne, D.H., Eds.; Springer: Boston, MA, USA, 2012; pp. 505-570.

21. Desmond, R.L.; Bassi, D. The Peach: Botany, Production and Uses; CABI: Wallingford, UK, 2008; 615p., ISBN 978-1-84593-386-9.

22. Li, X.; Meng, X.; Jia, H.; Yu, M.; Ma, R.; Wang, L.; Aranzana, M.J. Peach genetic resources: Diversity, population structure and linkage disequilibrium. BMC Genet. 2013, 14, 84. [CrossRef] [PubMed]

23. Charrier, G.; Ngao, J.; Saudreau, M.; Améglio, T. Effects of environmental factors and management practices on microclimate, winter physiology, and frost resistance in trees. Front. Plant Sci. 2015, 6, 259. [CrossRef] [PubMed]

24. Chakraborty, S.; Tiedemann, A.V.; Teng, P.S. Climate change: Potential impact on plant diseases. Environ. Pollut. 2000, 108, 317-326. [CrossRef]

25. Egilla, J.N.; Byrne, D.H. The search for peach root-stocks tolerant to alkalinity. Fruit Var. J. 1989, 43, 7-11.

26. Bernhard, R.; Grasselly, C. Les pêchers $\times$ amandiers. L'Arboric. Fruit. 1981, 328, 37-42.

27. Jiménez, S.; Pinochet, J.; Abadía, A.; Moreno, M.A.; Gogorcena, Y. Tolerance response to iron chlorosis of Prunus selections as rootstocks. HortScience 2008, 43, 304-309.

28. Pinochet, J.; Calvet, C.; Hernández-Dorrego, A.; Bonet, A.; Felipe, A.; Moreno, M.A. Resistance of peach and plum rootstocks from Spain, France, and Italy to root-knot nematode Meloidogyne javanica. HortScience 1999, 34, 1259-1262.

29. Gil-Albert, F. Tratado de Arboricultura Frutal, Vol IV: Técnicas de Mantenimiento del Suelo en Plantaciones Frutales; Mundi-Prensa Libros: Madrid, Spain, 1991; 109p., ISBN 978-84-8476-662-9.

30. Cummings, G.A. Effect of soil pH and calcium amendments on peach yield, tree growth and longevity. Acta Hortic. 1989, 254, 179-184. [CrossRef]

31. Font i Forcada, C.; Oraguzie, N.; Igartua, E.; Moreno, M.A.; Gogorcena, Y. Population structure and marker-trait association for pomological traits in peach and nectarine cultivars. Tree Genet. Genomes 2013, 9, 331-349. [CrossRef] 
32. Font i Forcada, C.; Gradziel, T.M.; Gogorcena, Y.; Moreno, M.A. Phenotypic diversity among local Spanish and foreign peach and nectarine (Prunus persica (L.) Batsch) accessions. Euphytica 2014, 197, 261-277. [CrossRef]

33. Bassi, D.; Moneté, R. Botany and Taxonomy. In The Peach: Botany, Production and Uses; Layne, D.R., Bassi, D., Eds.; CABI: Wallingford, UK, 2008; pp. 1-36, ISBN 978-1-84593-386-9.

34. Lee, M.H.; Bostock, R.M. Induction, regulation and role in pathogenesis of appressoria in Monilinia fructicola. Phytopathology 2006, 96, 1072-1080. [CrossRef] [PubMed]

35. Gogorcena, Y.; Cantín, C.M.; Jiménez, S. Fruit tree crops. In Agricultural Sciences: Topics in Modern Agriculture Breeding; Studium Press LLC: Houston, TX, USA, 2010.

36. Lombardo, V.A.; Osorio, S.; Borsani, J.; Lauxmann, M.A.; Bustamante, C.A.; Budde, C.O.; Andreo, C.S.; Lara, M.V.; Fernie, A.R.; Drincovich, M.F. Metabolic profiling during peach fruit development and ripening reveals the metabolic networks that underpin each developmental stage. Plant Physiol. 2011, 157, 1696-1710. [CrossRef] [PubMed]

37. Thomidis, T.; Tsipouridis, C.; Darara, V. Seasonal variation of nutrient elements in peach fruits (cv. May Crest) and its correlation with development of brown rot (Monilinia laxa). Sci. Hortic. 2007, 111, 300-301. [CrossRef]

38. United States Department of Agriculture (USDA). EU-28, Stone Fruit Annual. Available online: http: / /StoneFruitAnnual_Madrid_EU-28_8-22-2017.pdf (accessed on 19 January 2018).

39. Ministerio de Agricultura, Pesca, Alimentación y Medio Ambiente (MAPAMA). Available online: http:/ / www.mapama.gob.es/es/agricultura/temas/sanidad-vegetal/productos-fitosanitarios/registro/ menu.asp (accessed on 6 February 2018).

40. Oliveira-Lino, L.; Pacheco, I.; Mercier, V.; Faoro, F.; Bassi, D.; Bornard, I.; Quilot-Turion, B. Brown rot strikes Prunus fruit: An ancient fight almost always lost. J. Agric. Food Chem. 2016, 64, 4029-4047. [CrossRef] [PubMed]

41. Dugan, M.F. The Identification of Fungi. An Illustrated Introduction with Keys, Glossary, and Guide to Literature; APS PRESS: Saint Paul, MN, USA, 2006; 176p., ISBN 2006 0-89054-336-4.

42. Kew Royal Botany Gardens. Kew Mycology Collection. Available online: http://apps.kew.org/herbtrack/ search? (accessed on 7 August 2018).

43. Hrustić, J.; Delibasić, G.; Stanković, I.; Grahovać, M.; Krstić, B.; Bulajić, A.; Tanović, B. Monilinia spp. causing brown rot of stone fruit in Serbia. Plant Dis. 2015, 99, 709-717. [CrossRef]

44. Žežlina, I.; Rot, M.; Kač, M.; Trdan, S. Causal agents of stone fruit diseases in Slovenia and the potential for diminishing their economic impact: A review. Plant Prot. Sci. 2016, 52, 149-157. [CrossRef]

45. Pascal, T.; Levigneron, A.; Kervella, J.; Ngyen-The, C. Evaluation of two screening methods for resistance of apricot, plum and peach to Monilinia laxa. Prog. Temp. Fruit Breed. 1994, 77, 19-23. [CrossRef]

46. Walter, M.; McLaren, G.F.; Fraser, J.A.; Frampton, C.M.; Boyd-Wilson, K.S.H.; Perry, J.H. Methods of screening apricot fruit for resistance to brown rot caused by Monilinia spp. Australas. Plant Pathol. 2004, 33, 541-547. [CrossRef]

47. Villarino, M.; Melgarejo, P.; de Cal, A. Growth and aggresiveness factors affecting Monilinia spp. survival in peaches. Int. J. Food Microbiol. 2016, 227, 6-12. [CrossRef] [PubMed]

48. Obi, V.I.; Barriuso, J.J.; Moreno, M.A.; Giménez, R.; Gogorcena, Y. Optimizing protocols to evaluate brown rot (Monilinia laxa) susceptibility in peach and nectarine fruits. Australas. Plant Pathol. 2017, 46, 183-189. [CrossRef]

49. Holb, I.J.; Szöke, S.; Abonyi, F. Temporal development and relationship amongst brown rot blossom blight, fruit blight and fruit rot in integrated and organic sour cherry orchards. Plant Pathol. 2013, 62, 799-808. [CrossRef]

50. Cimen, I.; Ertugrul, B.B. Determination of mycoflora in almond plantations under drought conditions in South-eastern Anatolia project region, Turkey. Plant Pathol. J. 2007, 6, 82-86.

51. Holb, I.J. Brown rot blight of pome and stone fruits: Symptom, disease cycle, host resistance, and biological control. Int. J. Hortic. Sci. 2008, 14, 15-21.

52. Poniatowska, A.; Michalecka, M.; Bieleni, A. Characteristic of Monilinia spp. fungi causing brown rot of pome and stone fruits in Poland. Eur. J. Plant Pathol. 2013, 135, 855-865. [CrossRef] 
53. Holb, I.J.; Scherm, H. Temporal dynamics of brown rot in different apple management systems and importance of dropped fruit for disease development. Phytopathology 2007, 97, 1104-1111. [CrossRef] [PubMed]

54. Hrustić, J.; Grahovac, M.; Mihajlović, M.; Delibašić, G.; Ivanović, M.; Nikolić, M.; Tanović, B. Molecular detection of Monilinia fructigena as causal agent of brown rot on quince. Pestic. Phytomed. 2012, 27, 15-24. [CrossRef]

55. Van Leeuwen, G.C.M.; Baayen, R.P.; Holb, I.J.; Jeger, M.J. Distinction of the Asiatic brown rot fungus Monilia polystroma sp. nov. from M. fructigena. Mycol. Res. 2002, 106, 444-451. [CrossRef]

56. De Cal, A.; Egüen, B.; Melgarejo, P. Vegetative compatibility groups and sexual reproduction among Spanish Monilinia fructicola isolates obtained from peach and nectarine orchards, but not Monilinia laxa. Fungal Biol. 2014, 118, 484-494. [CrossRef] [PubMed]

57. Bernat, M.; Segarra, J.; Xu, X.M.; Casals, C.; Usall, J. Influence of temperature on decay, mycelium development and sporodochia production caused by Monilinia fructicola and M. laxa on stone fruits. Food Microbiol. 2017, 64, 112-118. [CrossRef] [PubMed]

58. Holtz, B.A.; Michailides, T.J.; Hong, C. Development of apothecia from stone fruit infected and stromatized by Monilinia fructicola in California. Plant Dis. 1998, 82, 1375-1380. [CrossRef]

59. Zhu, X.-Q.; Niu, C.-W.; Chen, X.-Y.; Guo, L.-Y. Monilinia species associated with brown rot of cultivated apple and pear fruit in China. Plant Dis. 2016, 100, 2240-2250. [CrossRef]

60. Vasić, M.; Vico, I. Distribution and characterization of Monilinia spp. causing apple fruit decay in Serbia. Plant Dis. 2018, 102, 359-369. [CrossRef]

61. Petróczy, M.; Palkovics, L. First report of Monilia polystroma on apple in Hungary. Eur. J. Plant Pathol. 2009, 125, 343-347. [CrossRef]

62. Hu, M.; Cox, K.D.; Schnabel, G.; Luo, C.X. Monilinia species causing brown rot of peach in China. PLoS ONE 2011, 6, e24990. [CrossRef] [PubMed]

63. CABI. Distribution Maps of Plant Diseases. Available online: https://www.cabi.org/isc/ (accessed on 15 June 2018).

64. Adaskaveg, J.E.; Schnabel, G.; Förster, H. Diseases of peach caused by fungi and fungal-like organisms: Biology, epidemiology and management. In The Peach: Botany, Production and Uses; Bassi, D., Layne, D., Eds.; CABI: Wallingford, UK, 2008; pp. 352-406, ISBN 9781845933869.

65. Janisiewicz, W.J.; JurickIi, W.M.; Vico, I.; Peter, K.A.; Buyer, J.S. Culturable bacteria from plum fruit surfaces and their potential for controlling brown rot after harvest. Postharvest Biol. Technol. 2013, 76, 145-151. [CrossRef]

66. Villarino, M.; Melgarejo, P.; Usall, J.; Segarra, J.; de Cal, A. Primary inoculum sources of Monilinia spp. in Spanish peach orchards and their relative importance in brown rot. Plant Dis. 2010, 94, 1048-1054. [CrossRef]

67. Xu, X.M.; Bertone, C.; Berrie, A. Effects of wounding, fruit age and wetness duration on the development of cherry brown rot in the UK. Plant Pathol. 2007, 56, 114-119. [CrossRef]

68. Nagarajan, S.; Singh, D.V. Long-distance dispersion of rust pathogens. Ann. Rev. Phytopathol. 1990, 28, 139-153. [CrossRef] [PubMed]

69. Bosshard, E.; Hilber-Bodmer, M.; Scharer, H.-J.; Bunter, M.; Duffy, B. First report of the quarantine brown rot pathogen Monilinia fructicola on imported stone fruits in Switzerland. Plant Dis. 2006, 90, 1554. [CrossRef]

70. Ellis, M.A. Brown Rot of Stone Fruits. Available online: https://ohioline.osu.edu/factsheet/plpath-fru-29 (accessed on 29 January 2018).

71. Hong, C.; Holtz, B.A.; Morgan, D.P.; Michailides, T.J. Significance of thinned fruit as a source of the secondary inoculum of Monilinia fructicola in California nectarine orchards. Plant Dis. 1997, 81, 519-524. [CrossRef]

72. Kotleba, J. European and Mediterranean Plant Protection Organization (EPPO). Bull. OEPP/EPPO Bull. 2010, 40, 5-22. [CrossRef]

73. Thomidis, T. Influence of relative virulence and latent infections on the development of Monilinia to Greek peach orchards. Crop Prot. 2017, 94, 159-165. [CrossRef]

74. Fazekas, M.; Madar, A.; Sipiczki, M.; Miklós, I.; Holb, I.J. Genetic diversity in Monilinia laxa populations in stone fruit species in Hungary. World J. Microbiol. Biotechnol. 2014, 30, 1879-1892. [CrossRef] [PubMed]

75. Tian, S.P.; Bertolini, P. Effect of temperature during conidial formation of Monilinia laxa on conidial size, germination and infection of stored nectarines. J. Phytopathol. 1999, 147, 635-641. [CrossRef] 
76. Xu, X.M.; Robinson, J.D. Epidemiology of brown rot (Monilinia fructigena) on apple: Infection of fruits by conidia. Plant Pathol. 2000, 49, 201-206. [CrossRef]

77. Gell, I.; de Cal, A.; Torres, R.; Usall, J.; Melgarejo, P. Relationship between the incidences of latent infections caused by Monilinia spp. and the incidence of brown rot of peach fruit: Factors affecting latent infection. Eur. J. Plant Pathol. 2008, 121, 487-498. [CrossRef]

78. Casals, C.; Viñas, I.; Torres, R.; Griera, C.; Usall, J. Effect of temperature and water activity on in vitro germination of Monilinia spp. J. Appl. Microbiol. 2010, 108, 47-54. [CrossRef] [PubMed]

79. Angeli, S.S.; May de Mio, L.L.; Amorim, L. Comparative analysis of M. fructicola and M. laxa isolates from Brazil: Monocyclic components of peach brown rot. Cienc. Rural 2017, 47, 1-7. [CrossRef]

80. European and Mediterranean plant protection organization (EPPO). Diagnostics on Monilinia fructicola, specific approval and amendment. EPPO Bull. 2009, 39, 337-343.

81. De Cal, A.; Melgarejo, P. Effects of long-wave UV light on Monilinia growth and identification of species. Plant Dis. 1999, 83, 62-65. [CrossRef]

82. Van Leeuwen, G.C.M.; Kesteren, H.A. Delineation of the three brown rot fungi of fruit crops (Monilinia spp.) on the basis of quantitative characteristics. Can. J. Bot. 1998, 76, 2042-2050. [CrossRef]

83. European and Mediterranean plant protection organization (EPPO). Diagnostic protocols for regulated pests, Monilinia fructicola. EPPO Bull. 2003, 33, 281-288.

84. Petróczy, M.; Szigethy, A.; Palkkovics, L. Monilinia species in Hungary: Morphology, culture characteristics, and molecular analysis. Trees 2012, 26, 153-164. [CrossRef]

85. Côté, M.-J.; Tardif, M.-C.; Meldrum, A.J. Identification of Monilinia fructigena, M. fructicola, M. laxa, and Monilia polystroma on inoculated and naturally infected fruit using multiplex PCR. Plant Dis. 2004, 88, 1219-1225. [CrossRef]

86. American Phytopathological Society. Brown Rot of Stone Fruits. Available online: https://www. apsnet.org/edcenter/intropp/lessons/fungi/ascomycetes/Pages/BrownRotStoneFruits.aspx (accessed on 7 August 2018).

87. Gell, I.; Cubero, J.; Melgarejo, P. Two different PCR approaches for universal diagnosis of brown rot and identification of Monilinia spp. in stone fruit trees. J. Appl. Microbiol. 2007, 103, 2629-2637. [CrossRef] [PubMed]

88. Van Brouwershaven, I.R.; Bruil, M.L.; van Leeuwen, G.C.M.; Kox, L.F.F. A real-time (TaqMan) PCR assay to differentiate Monilinia fructicola from other brown rot fungi of fruit crops. Plant Pathol. 2010, 59, 548-555. [CrossRef]

89. Balodi, R.; Bisht, S.; Ghataka, A.; Rao, K.H. Plant disease diagnosis: Technological advancements and challenges. Indian Phytopath. 2017, 70, 275-281. [CrossRef]

90. Forster, H.; Adaskaveg, J.E. Early brown rot infections in sweet cherry fruit are detected by Monilinia-specific DNA primers. Phytopathology 2000, 90, 171-178. [CrossRef] [PubMed]

91. Ioos, R.; Frey, P. Genomic variation within Monilinia laxa, M. fructigena, and M. fructicola, and application to species identified by PCR. Eur. J. Plant Pathol. 2000, 106, 337-373. [CrossRef]

92. Boehm, E.W.A.; Ma, Z.; Michilides, T.J. Species-specific detention of Monilinia fructicola from California stone and flowers. Phytopathology 2001, 91, 428-439. [CrossRef] [PubMed]

93. Guinet, C.; Fourrier-Jeandel, C.; Cerf-Wendling, I.; Ioos, R. One-step detection of Monilinia fructicola, M. fructigena, and M. laxa on Prunus and Malus by a Multiplex Real-Time PCR assay. Plant Dis. 2016, 100, 2465-2474. [CrossRef]

94. Papavasileiou, A.; Madesis, P.B.; Karaoglanidis, G.S. Identification and differentiation of Monilinia species causing brown rot of pome and stone fruit using high-resolution melting (HRM) analysis. Phytopathology 2016, 106, 1055-1064. [CrossRef] [PubMed]

95. Garcia-Benitez, C.; Melgarejo, P.; de Cal, A. Detection of latent Monilinia infections in nectarine flowers and fruit by qPCR. Plant Dis. 2017, 101, 1002-1008. [CrossRef]

96. Garcia-Benitez, C.; Melgarejo, P.; Beniusis, A.; Guinet, C.; Özben, S.; Degirnen, K.I.; Valente, M.T.; Riccioni, L.; de Cal, A. Proficiency of real-time PCR detection of latent Monilinia spp. infection in nectarine flowers and fruit. Phytopathol. Mediterr. 2017, 56, 242-250. [CrossRef]

97. Ma, Z.; Luo, Y.; Michailides, T.J. Nested PCR assays for detection of Monilinia fructicola in stone fruit orchards and Botryosphaeria dothidea from pistachios in California. J. Phytopathol. 2003, 151, 312-322. [CrossRef] 
98. Miessner, S.; Stammler, G. Monilinia laxa, M. fructigena and M. fructicola: Risk estimation of resistance to QoI fungicides and identification of species with cytochrome b gene sequences. J. Plant Dis. Prot. 2010, 117, 162-167. [CrossRef]

99. Hily, J.-M.; Singer, S.D.; Villani, S.M.; Cox, K.D. Characterization of the cytochrome b (cyt b) gene from Monilinia species causing brown rot of stone and pome fruit and its significance in the development of QoI resistance. Pest Manag. Sci. 2010, 67, 385-396. [CrossRef] [PubMed]

100. Ma, Z.H.; Yoshimura, M.A.; Holtz, B.A.; Michailides, T.J. Characterization and PCR-based detection of benzimidazole-resistant isolates of Monilinia laxa in California. Pest Manag. Sci. 2005, 61, 449-457. [CrossRef] [PubMed]

101. Lowe, C.-W.; Satterfield, B.A.; Nelson, D.B.; Thiriot, J.D.; Heder, M.J.; March, J.K.; Drake, D.S.; Lew, C.S.; Bunnell, A.J.; Moore, E.S.; et al. A quadruplex real-time PCR assay for the rapid detection and differentiation of the most relevant members of the B. pseudomallei Complex: B. mallei, B. pseudomallei, and B. thailandensis. PLOS ONE 2016, 11, e0164006. [CrossRef] [PubMed]

102. Ivic, D.; Fazini, T.; Cole, J.; Novak, A. Monilinia species identified on peach and nectarine in Croatia, with the first record of Monilinia fructicola. Bull. OEPP/EPPO Bull. 2014, 44, 70-72. [CrossRef]

103. Riccioni, L.; Valente, M.T. Comparison of different PCR tests to identify Monilinia fructicola. Bull. OEPP/EPPO Bull. 2015, 45, 33-40. [CrossRef]

104. Raja, H.A.; Miller, A.N.; Pearce, C.J.; Oberlies, N.H. Fungal identification using molecular tools: A primer for the natural products research community. J. Nat. Prod. 2017, 80, 756-770. [CrossRef] [PubMed]

105. Garcia-Benitez, C.; Melgarejo, P.; de Cal, A.; Fontaniella, B. Microscopic analyses of latent and visible Monilinia fructicola infections in nectarines. PLOS ONE 2016, 11, e0160675. [CrossRef] [PubMed]

106. Papavasileiou, A.; Testempasis, S.; Michailides, T.J.; Karaoglanidis, G.S. Frequency of brown rot fungi on blossoms and fruit in stone fruit orchards in Greece. Plant Pathol. 2015, 64, 416-424. [CrossRef]

107. Thomidis, T.; Exadaktylou, E. Effect of boron on the development of brown rot (Monilinia laxa) on peaches. Crop Prot. 2010, 29, 572-576. [CrossRef]

108. Sisquella, M.; Casals, C.; Picouet, P.; Viñas, I.; Torres, R.; Usall, J. Immersion of fruit in water to improve radio frequency treatment to control brown rot in stone fruit. Postharvest Biol. Technol. 2013, 80, 31-36. [CrossRef]

109. Pascual, S.; Rico, J.R.; de Cal, A.; Melgarejo, P. Eco-physiological factors affecting growth, sporulation and survival of the biocontrol agent Penicillium oxalicum. Mycopathologia 1997, 139, 43-50. [CrossRef] [PubMed]

110. Maharshi, A.R.; Thaker, V.S. Growth and development of plant pathogenic fungi in define media. Eur. J. Exp. Biol. 2012, 2, 44-54.

111. Holb, I.J. Effect of acidity on growth rate and stroma formation of Monilinia fructigena and M. polystroma isolates. Int. J. Hortic. Sci. Hung. 2004, 10, 63-67.

112. Romero-Arenas, O.; Damián-Huato, M.A.; Treviño, I.H.; Parraguire-Lezama, J.F.C.; Aragón-García, A.; Arellano, A.D. Effect of $\mathrm{pH}$ on growth of the mycelium of Trichoderma viride and Pleurotus ostreatus in solid cultivation mediums. Afr. J. Agric. Res. 2012, 7, 4724-4730. [CrossRef]

113. Dirlewanger, E.; Moing, A.; Rothan, C.; Svanella, L.; Pronier, V.; Guye, A.; Plomion, C.; Monet, R. Mapping QTLs controlling fruit quality in peach (Prunus persica (L.) Batsch. Theor. App. Genet. 1999, 98, 18-31. [CrossRef]

114. Tyl, C.; Sadler, G.D. pH and Titratable Acidity. In Food Analysis; Nielsen, S., Ed.; Springer: Cham, Switzerland, 2017; pp. 389-406.

115. Lobit, P.; Soing, P.; Genard, M.; Habib, R. Theoretical analysis of relationships between composition, $\mathrm{pH}$ and titratable acidity of peach fruit. J. Plant Nutr. 2002, 25, 2775-2792. [CrossRef]

116. Yamanaka, $\mathrm{T}$. The effect of $\mathrm{pH}$ on the growth of saprotrophic and ectomycorrhizal ammonia fungi in vitro. Mycologia 2003, 95, 584-589. [CrossRef] [PubMed]

117. De Cal, A.; España, P.S.; Martinez, F.; Egüen, B.; Chien-Ming, C.; Lee, M.H.; Melgarejo, P.; Prusky, D. Role of gluconic acid and $\mathrm{pH}$ modulation in virulence of Monilinia fructicola on peach fruit. Postharvest Biol. Technol. 2013, 86, 418-423. [CrossRef]

118. Fazinic, T.; Lovrek, I.Z.; Ivic, D. Potential impact and management of Monilinia fructicola in an integrated peach orchard. Agric. Conspec. Sci. 2017, 82, 27-31.

119. Minas, I.S.; Tanou, G.; Molassiotis, A. Environmental and orchard bases of peach fruit quality. Sci. Hortic. 2018, 235, 307-322. [CrossRef] 
120. Bevacqua, D.; Quilot-Turion, B.; Bolzoni, L. A model for temporal dynamics of brown rot spreading in fruit orchards. Phytopathology 2018, 108, 595-601. [CrossRef] [PubMed]

121. De Cal, A.; Sagasta, E.M.; Melgarejo, P. Biological control of peach twig blight (Monilinia laxa) with Penicillium frequentans. Plant Pathol. 1990, 39, 612-618. [CrossRef]

122. Larena, I.; Melgarejo, P. Biological Control of Monilinia laxa and Fusarium oxysporum f. sp. lycopersici by a lytic enzyme-producing Penicillium purpurogenum. Biol. Control 1996, 6, 361-367. [CrossRef]

123. Dicklow, M.B. Biofungicides: Commercial Horticulture. Available online: https://ag.umass.edu/ greenhouse-floriculture/fact-sheets/biofungicides (accessed on 17 February 2018).

124. Bonaterra, A.; Mari, M.; Casalini, L.; Montesinos, E. Biological control of Monilinia laxa and Rhizopus stolonifer in postharvest of stone fruit by Pantoea agglomerans EPS125 and putative mechanisms of antagonism. Int. J. Food Microbiol. 2003, 84, 93-104. [CrossRef]

125. Larena, I.; Torres, R.; de Cal, A.; Liñán, M.; Melgarejo, P.; Domenichini, P.; Bellini, A.; Mandein, J.F.; Lichou, J.; Ochoa de Eribe, X.; et al. Biological control of postharvest brown rot (Monilinia spp.) of peaches by field application of Epicoccum nigrum. Biol. Control. 2005, 32, 305-310. [CrossRef]

126. Yánez-Mendizábal, V.; Zeriouh, H.; Viña, I.; Torres, R.; Usall, J.; de Vicente, A.; Pérez-García, A.; Teixidó, N. Biological control of peach brown rot (Monilinia spp.) by Bacillus subtilis CPA-8 is based on production of fengycin-like lipopeptides. Eur. J. Plant Pathol. 2012, 132, 609-619. [CrossRef]

127. Guijarro, B.; Melgarejo, P.; Torres, R.; Lamarca, N.; Usall, J.; de Cal, A. Penicillium frequentans population dynamics on peach fruits after its applications against brown rot in orchards. Appl. Microbiol. Biotechnol. 2008, 104, 659-671. [CrossRef] [PubMed]

128. Gotor-Vila, A.; Teixidó, N.; Casals, C.; Torres, R.; de Cal, A.; Guijarro, B.; Usall, J. Biological control of brown rot in stone fruit using Bacillus amyloliquefaciens CPA-8 under field conditions. Crop Prot. 2017, 102, 72-80. [CrossRef]

129. Giobbe, S.; Marceddu, S.; Scherm, B.; Zara, G.; Mazzarello, V.L.; Budroni, M.; Migheli, Q. The strange case of a biofilm-forming strain of Picia fermentans, which controls Monilinia brown rot on apple but is pathogenic on peach fruit. FEMS Yeast Res. 2007, 7, 1389-1398. [CrossRef] [PubMed]

130. Adaskaveg, J.E.; Gubler, D.; Michailides, T. Fungicides, Bactericides, and Biological Fro Deciduous Tree Fruit, Nut, Strawberry, and Vine Crops. Available online: http://ipm.ucanr.edu/PDF/PMG/ fungicideefficacytiming.pdf. (accessed on 30 July 2018).

131. De Cal, A.; Sagasta, E.M.; Melgarejo, P. Antifungal substances produced by Penicillium frequentans and their relationship to the biocontrol of Monilinia laxa. Phytopathology 1988, 78, 888-893. [CrossRef]

132. Norton, G.W.; Rajotte, E.G.; Gapud, V. Participatory research in integrated pest management: Lessons from the IPM CRSP. Agric. Hum. Values 1999, 16. [CrossRef]

133. Egüen, B.; Melgarejo, P.; de Cal, A. The effect of fungicide resistance on the structure of Monilinia laxa populations in Spanish peach and nectarine orchards. Eur. J. Plant Pathol. 2016, 145, 815-827. [CrossRef]

134. Katan, T.; Shabi, E. Resistance to dicarboximide fungicides in laboratory isolates of Monilinia laxa. Neth. J. Plant Pathol. 1981, 87, 242.

135. Cañez, U.M., Jr.; Ogawa, J.M. Parasitic fitness of benomyl-resistant and benomyl-sensitive Monilinia laxa. Phytopathology 1985, 20, 167-192.

136. Pimentel, D. Environmental and economic costs of the application of pesticides primarily in the United States? Environ. Dev. Sustain. 2005, 7, 229-252. [CrossRef]

137. Zehr, E.I. Control of brown rot in peach orchards. Plant Dis. 1982, 66, 1101-1105. [CrossRef]

138. Liu, J.; Sui, Y.; Wisniewski, M.; Droby, S.; Tian, S.; Norelli, H.V. Effect of heat treatment on inhibition of Monilinia fructicola and induction of disease resistance in peach fruit. Postharvest Biol. Technol. 2012, 65, 61-68. [CrossRef]

139. Elmer, P.A.G.; Gaunt, R.E. The biological characteristics of dicarboximides resistant isolates of Monilinia fructicola from New Zeland stone orchards. Plant Pathol. 1994, 43, 130-137. [CrossRef]

140. Chen, F.; Liu, X.; Schnabel, G. Field strains of Monilinia fructicola resistant to both MBC and DMI fungicides isolated from stone fruit orchards in the eastern United States. Plant Dis. 2013, 97, 1063-1068. [CrossRef]

141. European Commission. Integrated Pest Management. Available online: https://ec.europa.eu/food/plant/ pesticides/sustainable_use_pesticides/ipm_en (accessed on 28 July 2018). 
142. Solomon, R.D.J.; Kallidass, S.; Vimalan, J. Isolation, identification and study of antimicrobial property of a bioactive compound in an Indian medicinal plant Acalypha indica (Indian-nettle). World J. Microbiol. Biotechnol. 2005, 21, 1231-1236. [CrossRef]

143. Suleiman, M.N.; Emua, S.A. Efficacy of four plant extracts in the control of root rot disease of cowpea (Vigna unguiculata [L.] Walp). Afr. J. Biotechnol. 2009, 8, 3806-3808.

144. Khaled-Khodja, N.; Boulekbache-Makhlouf, L.; Madani, K. Phytochemical screening of antoxidant and antibacterial activities of methanolic extracts of some Lamiaceae. Ind. Crops Prod. 2014, 61, 41-48. [CrossRef]

145. Yoon, M.-Y.; Cha, B.; Kim, J.-C. Recent trends in studies on botanical fungicides in Agriculture. Plant Pathol. J. 2013, 29, 1-9. [CrossRef] [PubMed]

146. Parveen, S.; Wani, A.H.; Bhat, M.Y.; Koka, J.A. Biological control of postharvest fungal rots of rosaceous fruits using microbial antagonists and plant extracts: A review. Czech Mycol. 2016, 68, 41-66.

147. Wilson, C.L.; Solar, J.M.; El-Ghaouth, A.; Wisniewski, M.E. Rapid evaluation of plant extracts and essential oils for antifungal activity against Botrytis cinerea. Plant Dis. 1997, 81, 204-210. [CrossRef]

148. Ziedan, E.H.E.; Farrag, E.S.H. Fumigation of peach fruits with essential oils to control postharvest decay. Res. J. Agric. Biol. Sci. 2008, 4, 512-519.

149. Kouass, K.H.S.; Baiji, M.; Zhiri, A.; Lepoivre, P.; Jijaku, M.H. Evaluation of three essential oils as potential sources of botanical fungicide. Commun. Agric. Appl. Biol. Sci. 2010, 75, 525-529.

150. Hassani, A.; Fathi, Z.; Ghosta, Y.; Abdollahi, A.; Meshkatalsadat, M.H.; Marandi, R.J. Evaluation of plant essential oils for control of postharvest brown and gray mold rots on apricot. J. Food Saf. 2012, 32, 94-101. [CrossRef]

151. Goncalves, F.P.; Martins, M.C.; Junior, G.J.S.; Lourenco, S.A.; Amorim, L. Postharvest control of brown rot and Rhizopus rot in plums and nectarines using carnauba wax. Postharvest Biol. Technol. 2010, 58, $211-217$. [CrossRef]

152. Ganchev, D.A. Preliminarily study of antifungal activity of some active substances from plant origin according to Monilia fructigena. Bulg. J. Agric. Sci. 2007, 13, 679-682.

153. Carović-Stanko, K.; Fruk, G.; Satovic, Z.; Ivić, D.; Politeo, O.; Sever, Z.; Grdiša, M.; Strikić, F.; Jemrić, T. Effects of Ocimum spp. essential oil on Monilinia laxa in-vitro. J. Essent. Oil Res. 2013, 25, 143-148. [CrossRef]

154. Lopez-Reyes, J.G.; Spadaro, D.; Prelle, A.; Garbaldi, A.; Gullino, M.L. Efficacy of plant essential oils on postharvest control of rots caused by fungi on different stone fruits in vivo. J. Food Prot. 2013, 76, 631-639. [CrossRef] [PubMed]

155. Cindi, M.D.; Soundy, P.; Romanazzi, G.; Sivakumar, D. Different defence responses and brown rot control in two Prunus persica cultivars to essential oil vapours after storage. Postharvest Biol. Technol. 2016, 119, 9-17. [CrossRef]

156. Jemric, T.; Ivic, D.; Fruk, G.; Matijas, H.S.; Cvjetkovic, B.; Bupic, M.; Pavkovic, B. Reduction of postharvest decay of peach and nectarine caused by Monilinia laxa using hot water dipping. Food Bioprocess Technol. 2011, 4, 149-154. [CrossRef]

157. Casals, C.; Elmer, P.A.G.; Viñas, I.; Teixidó, N.; Sisquella, M.; Usall, J. The combination of curing with either chitosan or Bacillus subtilis CPA-8 to control brown rot infections caused by Monilinia fructicola. Postharvest Biol. Technol. 2012, 64, 126-132. [CrossRef]

158. Bernat, M.; Segarra, J.; Casals, C.; Teixidó, N.; Torres, R.; Usall, J. Relevance of the main postharvest handling operations on the development of brown rot disease on stone fruits. J. Sci. Food Agric. 2017, 97, 5319-5326. [CrossRef] [PubMed]

159. Spadoni, A.; Guidarelli, M.; Sanzani, S.M.; Ippolito, A.; Mari, M. Influence of hot water treatment on brown rot of peach and rapid fruit response to heat stress. Postharvest Biol. Technol. 2014, 94, 66-73. [CrossRef]

160. Sisquella, M.; Viñas, I.; Picouet, P.; Torres, R.; Usall, J. Effect of host and Monilinia spp. variables on the efficacy of radio frequency treatment on peaches. Postharvest Biol. Technol. 2014, 87, 6-12. [CrossRef]

161. Feliciano, A.; Feliciano, A.J.; Ogawa, J.M. Monilinia fructicola resistance in the peach cv. Bolinha. Phytopathology 1987, 77, 776-780. [CrossRef]

162. Fresnedo-Ramírez, J.; Famula, T.R.; Gradziel, T.M. Application of a Bayesian ordinal animal model for the estimation of breeding values for the resistance to Monilinia fructicola (G. Winter) Honey in progenies of peach (Prunus persica (L.) Batsch). Breed. Sci. 2017, 67, 110-122. [CrossRef] [PubMed]

163. Gradziel, T.M. Changes in susceptibility to brown rot with ripening in three clingstone peach genotypes. J. Am. Soc. Hortic. Sci. 1994, 119, 101-103. 
164. Byrne, D.H. Trends in stone fruit cultivars development. Horticulture 2005, 15, 494-500.

165. Vallad, G.E.; Goodman, R.M. Systemic acquired resistance and induced systemic resistance in conventional agriculture. Crop Sci. 2004, 44, 1920-1934. [CrossRef]

166. Norton, G.A. Analysis of decision making in crop protection. Agro-Ecosystems 1976, 3, 27-44. [CrossRef]

167. Dodds, K.; Coleman, A.; Browne, B. Orchard Plant Protection Guide for Deciduous Fruits in NSW, 2017-2018. Available online: http://www.dpi.nsw.gov.au/data/assets/pdf_file/0006/249729/orchardplant-protection-guide-2017-18.pdf (accessed on 22 January 2018).

168. Tarbath, M.P.; Measham, P.F.; Glen, M.; Barry, K.M. Host factors related to fruit rot of sweet cherry (Prunus avium L.) caused by Botrytis cinerea. Australas. Plant Pathol. 2014, 43, 513-522. [CrossRef]

169. Compean, K.L.; Ynalvez, R.A. Antimicrobial activity of plant secondary metabolites. J. Med. Plant. Res. 2014, 8, 204-213.

170. Kasote, D.M.; Katyare, S.S.; Hegde, M.V.; Bae, H. Significance of antioxidant potential of plants and its relevance to therapeutic applications. Int. J. Biol. Sci. 2015, 11, 982-991. [CrossRef] [PubMed]

171. Chérif, M.; Arfaoui, A.; Rhaiem, A. Phenolic compounds and their role in bio-control and resistance of chickpea to fungal pathogenic attacks. Tunis. J. Plant Prot. 2007, 2, 7-21.

172. Prasad, D.; Singh, A.; Singh, K.P.; Bist, S.; Tewari, A.; Singh, U.P. The role of phenolic compounds in disease resistance in geranium. Arch. Phytopathol. Plant Prot. 2010, 43, 615-623. [CrossRef]

173. Sanzani, S.M.; Schena, L.; Ippolito, A. Effectiveness of phenolic compounds against citrus green mould. Molecules 2014, 19, 12500-12508. [CrossRef] [PubMed]

174. Tomás-Barberán, F.A.; Gil, M.I.; Cremin, P.; Waterhouse, A.L.; Hess-Pierce, B.; Kader, A.A. HPLC-DAD-ESIMS Analysis of phenolic compounds in nectarines, peaches, and plums. J. Agric. Food Chem. 2001, 4, 4748-4760. [CrossRef]

175. Villarino, M.; Sandín-España, P.; Melgarejo, P.; de Cal, A. High chlorogenic and neochlorogenic acid levels in immature peaches reduce Monilinia laxa infection by interfering with fungal melanin biosynthesis. J. Agric. Food Chem. 2011, 59, 3205-3213. [CrossRef] [PubMed]

176. Usall, J.; Ippolito, A.; Sisquella, M.; Neri, F. Physical treatment to control posthavest disease of fresh fruits and vegetables. Postharvest Biol. Technol. 2016, 122, 30-40. [CrossRef]

177. Spiers, T.M.; Elmer, P.A.G.; Wood, P.N.; Regglinski, T.; Tate, K.G. Multiple strategies for effective pathogen control. N. Z. Plant 2005, 58, 62-67.

178. Rubos, A.; Thomidis, T.; Tsipouridis, C.; Navrozidis, E.; Michailidou, O. Susceptibility of peach-nectarine cultivars on brown rot infections. Ann. Univ. Oradea Fascicle Environ. Prot. 2008, 13, 214-217.

179. Martínez-Gómez, P.; Sánchez, P.R.; Rubio, M.; Dicenta, F.; Gradziel, T.M.; Sozzi, G.O. Application of recent biotechnologies to Prunus tree crop genetic improvement. Ciencia e Investigación Agraria 2005, 32, 73-96. [CrossRef]

180. Martínez-García, P.J.; Parfitt, D.E.; Bostock, R.M.; Fresnedo-Ramírez, J.; Vazquez-Lobo, A.; Ogundiwin, E.A.; Crisosto, C.H. Application of genomic and quantitative genetic tools to identify candidate resistance genes for brown rot resistance in peach. PLoS ONE 2013, 8, e78634. [CrossRef] [PubMed]

181. Pacheco, I.; Bassi, D.; Eduardo, I.; Ciacciulli, A.; Pirona, R.; Rossini, L. QTL mapping for brown rot (Monilinia fructigena) resistance in an intraspecific peach (Prunus persica L. Batsch) F1 progeny. Tree Genet. Genomes 2014, 10, 1223-1242. [CrossRef]

182. Mari, M.; Spadoni, A.; Ceredi, G. Alternative technologies to control postharvest diseases of kiwifruit. Stewart Postharvest Rev. 2015, 4, 1-5.

183. Teksur, P.K. Alternative technologies to control postharvest diseases of pomegranate. Stewart Postharvest Rev. 2015, 4, 1-7. [CrossRef]

184. Verde, I.; Jenkins, J.; Dondini, L.; Micali, S.; Pagliarani, G.; Vendramin, E.; Schmutz, J. The Peach v2.0 release: High-resolution linkage mapping and deep resequencing improve chromosome-scale assembly and contiguity. BMC Genom. 2017, 18, 225. [CrossRef] [PubMed]

185. Gradziel, T.M.; Wang, D. Evaluation of brown rot resistance and its relation to enzymatic browning in clingstone peach germplasm. J. Am. Soc. Hortic. Sci. 1993, 118, 675-679.

186. Christen, D.; Motry, L.; Devènes, G. Comparison of three different evaluation methods of Monilinia laxa impact on apricot flowers. Acta Hortic. 2012, 966, 143-147. [CrossRef]

187. Obi, V.I.; Barriuso, J.J.; Saidani, F.; Aubert, C.; Gogorcena, Y. The tolerance of commercial peach cultivars to brown rot by Monilinia laxa is modulated by its antioxidant content? Sci. Hortic., submitted. 
188. Paunovic, S.A.; Paunovic, A.S. Investigation of peach germplasm (Prunus persica spp. 372 vulgaris = Vineyard peach) in-situ in Yugoslavia. Acta Hortic. 1996, 374, 201-207. [CrossRef]

189. Biggs, A.R.; Miller, S.S. Comparative relative susceptibility of NE-183 apple cultivars to fruit rot pathogens in West Virginia. J. Am. Pomol. Soc. 2005, 59, 72-77.

190. Biggs, A.R.; Northover, J. Early and late season susceptibility of peach fruits to Monilinia fructicola. Plant Dis. 1988, 72, 1070-1074. [CrossRef]

191. Northover, J.; Biggs, A.R. Susceptibility of immature and mature sweet and sour cherries to Monilinia fructicola. Plant Dis. 1990, 74, 280-284. [CrossRef]

192. Bassi, D.; Rizzo, M.; Cantoni, L. Assaying brown rot [(Monilinia laxa Aderh. \& Ruhl. (Honey)] susceptibility in peach cultivars and progeny. Acta Hortic. 1998, 465, 715-721. [CrossRef]

193. Jansch, M.; Frey, J.E.; Hilber-Bodmer, M.; Broggini, G.A.L.; Weger, J.; Schnabel, G.; Patocchi, A. SSR marker analysis of Monilinia fructicola from Swiss apricots suggests introduction of the pathogen from neighbouring countries and the United States. Plant Pathol. 2012, 61, 247-254. [CrossRef]

194. Keske, C.; May-De Mio, L.L.; Amorim, L. Spatial pattern of brown rot within peach trees related to inoculum of Monilinia fructicola in organic orchard. J. Plant Pathol. 2013, 95, 67-73.

195. Keske, C.; Amorim, L.; May-de Mio, L.L. Peach brown rot incidence related to pathogen infection at different stages of fruit development in an organic peach production system. Crop Prot. 2011, 30, 802-806. [CrossRef]

(C) 2018 by the authors. Licensee MDPI, Basel, Switzerland. This article is an open access article distributed under the terms and conditions of the Creative Commons Attribution (CC BY) license (http://creativecommons.org/licenses/by/4.0/). 